\title{
Mycologia
}

\section{Nivicolous Trichiales from the austral Andes: unexpected diversity including two new species}

\section{Anna Ronikier , Iván García-Cunchillos , Paulina Janik \& Carlos Lado}

To cite this article: Anna Ronikier , Iván García-Cunchillos , Paulina Janik \& Carlos Lado (2020) Nivicolous Trichiales from the austral Andes: unexpected diversity including two new species, Mycologia, 112:4, 753-780, DOI: 10.1080/00275514.2020.1759978

To link to this article: https://doi.org/10.1080/00275514.2020.1759978

+ View supplementary material $\longleftarrow$

曲 Published online: 10 Jul 2020.

Submit your article to this journal $[\pi$

III Article views: 160

Q View related articles $๘$

View Crossmark data

Citing articles: 2 View citing articles 


\title{
Nivicolous Trichiales from the austral Andes: unexpected diversity including two new species
}

\author{
Anna Ronikier $\mathbb{D}^{\mathrm{a}}$, Iván García-Cunchillos $\mathbb{D}^{\mathrm{b}}$, Paulina Janik $\mathbb{( D}^{\mathrm{a}}$, and Carlos Lado $\mathbb{D}^{\mathrm{b}}$ \\ aW. Szafer Institute of Botany, Polish Academy of Sciences, Lubicz 46, 31-512 Kraków, Poland; bReal Jardín Botánico, Consejo Superior de \\ Investigaciones Científicas, Plaza de Murillo 2, 28014 Madrid, Spain
}

\begin{abstract}
Nivicolous myxomycetes are a group of amoebozoan protists dependent on long-lasting snow cover worldwide. Recent fine-scale analysis of species diversity from the austral Andes revealed high intraspecific variability of most taxa, suggesting independent evolutionary processes and significant differences in species compositions between the Northern $(\mathrm{NH})$ and Southern $(\mathrm{SH})$ Hemispheres. The present study is the second part of this analysis based on representatives of Trichiales. A total of 173 South American collections were studied based on morphological and molecular data, and 15 taxa have been identified. Two of them, Hemitrichia crassifila and Perichaena patagonica, are proposed as new species confirmed by a phylogeny of Trichiales. However, their affinity to the genera in which they are proposed are not confirmed due to polyphyletic character of all genera of Trichiales. Four species, Dianema subretisporum, Trichia contorta var. karstenii, T. nivicola, and T. sordida, are reported for the first time from the Southern Hemisphere. One species, T. alpina, is new for Argentina. Additionally, we provide the first record of Perichaena megaspora from Chile. Specimen frequency and species diversity of Trichiales found at nivicolous localities in the austral Andes are unexpectedly high, exceeding those of Stemonitidales, the most numerous group in the Northern Hemisphere, where Trichiales play a marginal role. By contrast, Trichiales appear the main component of nivicolous assemblages in the Andes. Results of the present work, together with the earlier analysis of Stemonitidales, indicate that the Andes constitute an exceptionally important evolutionary hot spot for nivicolous myxomycetes characterized by an outstanding species diversity.
\end{abstract}

\section{ARTICLE HISTORY}

Received 5 June 2019

Accepted 21 April 2020

\section{KEYWORDS}

Amoebozoa; Argentina; Chile; Myxomycetes; neotropics; SEM; species distribution; 2 new taxa

\section{INTRODUCTION}

Myxomycetes G. Winter (plasmodial slime molds) is a group of Amoebozoa (Kang et al. 2017) that colonize all terrestrial ecosystems (Stephenson et al. 2008). Their distinctive character among protists is the presence of multinucleate plasmodia that move by fast-shuttle protoplasmic streaming and transform into static fruiting bodies filled with spores (Poulain et al. 2011). They occur in various vegetation types and are adapted to extreme environmental and climatic conditions, from high mountain areas to deserts (Liu et al. 2015; Lado et al. 2016; Schnittler et al. 2017). Nivicolous myxomycetes are a group particularly interesting from the ecological and evolutionary points of view. They are characterized by clearly defined habitat requirements and life cycle connected with mountainous regions and spring/early summer period, when the accumulation of winter snow begins to melt (Meylan 1932; Bozonnet et al. 1991; Lado 2004; Ronikier and Ronikier 2009). Their plasmodia (trophic stage) develop under the melting snow cover, and sporophores are formed at the limit of the melting snow on living plants (shrubs or alpine grasses), or remnants of dead plants (forest timber, litter) released from snow. Knowledge of the global diversity and biogeography of nivicolous myxomycetes is scarce, but these organisms are widely treated as cosmopolitan, and it is generally assumed that the same species and their assemblages occur in all mountains worldwide where periodic snow cover is present (see literature cited by Ronikier and Ronikier 2009).

A taxonomic analysis of nivicolous Stemonitidales T. Macbr. from the Andes has revealed that most "ubiquitous" species found in these mountains are morphologically diverse and divergent from related populations in other regions of the world, which suggests that they may represent distinct genetic lineages (Ronikier and Lado 2015). We also reported several putative endemic species that are common in the Andes and have not been found elsewhere (Ronikier and Lado 2013, 2015; Ronikier et al. 2013). Our first results were based on analysis of morphological variability of species belonging to the order Stemonitidales (Ronikier and Lado 
2015), whereas the present study explores the diversity and taxonomy of the order Trichiales T. Macbr. and verifies the phylogenetic position of nivicolous Trichiales described from the austral Andes.

The order Trichiales belongs to the group of brightspored species considered to be one of the two main evolutionary lineages in the class Myxomycetes (FioreDonno et al. 2005, 2019). Based on a morphological species concept, the order currently comprises four families, 14 genera, and 184 species (Lado and Eliasson 2017). Representatives of the Trichiales are not frequently reported from nivicolous localities, and only 11 species have been considered strictly nivicolous, namely, 5 species of the genus Dianema Rex (D. aggregatum Kowalski, D. inconspicuum Poulain, Mar. Mey. \& Bozonnet, D. leptotrichum A. Sánchez, G. Moreno \& A. Castillo, D. nivale (Meyl.) G. Lister, and D. subretisporum Kowalski), 2 species of the genus Hemitrichia Rostaf. (H. montana (Morgan) T. Macbr. and H. montanoides Mar. Mey. \& Poulain), 3 species of the genus Trichia Haller (T. alpina (R.E. Fr.) Meyl., T. nivicola Kuhnt, and T. sordida Johannesen), all described from the Northern Hemisphere $(\mathrm{NH})$, and 1 species of the genus Perichaena Fr. (P. megaspora A. Ronikier, Lado \& D. Wrigley), recently described from the austral Andes in the Southern Hemisphere (SH) (Ronikier et al. 2013). Most of the species are, however, rare and/or restricted to a limited geographic area. For instance, $D$. inconspicuum is known only from the French Alps in Europe (Poulain et al. 2011) and Perichaena megaspora from the Andes (Ronikier et al. 2013).

Data on nivicolous species of Trichiales reported to date from South America are scanty, since only two species have been recorded: the abovementioned P. megaspora from Argentina (Ronikier et al. 2013) and Trichia alpina from Chile (Lado et al. 2013). The primary aim of the present study is a taxonomic revision of specimens belonging to the order Trichiales collected in the snow melting period in the austral Andes (South America). Based on the detailed taxonomic study of this group, we attempt to test earlier observations based on the order Stemonitidales (Ronikier and Lado 2015). In particular, we address the following questions: (i) Is the species diversity in the studied part of the $\mathrm{SH}$ similar to that observed in the $\mathrm{NH}$ or, as revealed for Stemonitidales, do representatives of the order Trichiales in the austral Andes show a different pattern of species assemblages? (ii) Is the incidence of Trichiales in the Andean nivicolous communities different from that observed among $\mathrm{NH}$ species? (iii) Can putative endemic nivicolous species for the Andes be found among representatives of the Trichiales, further supporting the role the Andes may play in myxomycete species diversification?

\section{MATERIALS AND METHODS}

Material.-Samples were collected in the framework of the Myxotropic Project (www.myxotropic.org) during four expeditions carried out over four consecutive years (2006-2009) to the austral Andean part of South America. In total, 37 localities in Argentina were surveyed and georeferenced.

Morphological studies.-Morphological characters of each Andean collection were compared with published descriptions and illustrations of a given species. For direct comparisons (e.g., measurements) of characters with $\mathrm{NH}$ collections, 41 additional herbarium specimens of Trichiales, including original material as defined by the ICN (Turland et al. 2018) or type specimens (Dianema harveyi Rex, Dianema nivale, Hemitrichia intorta (Lister) Lister, Trichia sordida), from Europe and North America, preserved at the herbaria AH, BM, BPI, BR, KR, KRAM, M, MA and O (Thiers [continuously updated]), were studied. All of these materials are listed in the "Other specimen(s) examined" section of a given species.

Observations and measurements of morphological characters were conducted under Nikon SMZ 1000 and SMZ1500 stereoscopic microscopes (Nikon, Tokyo, Japan). The total height of the sporocarps, as well as the height and the width of the sporothecae of most mature individuals, was measured. The number of measured sporophores $(\mathrm{n})$ is provided with each species description. Observations and measurements of microscopic characters were made on material mounted in Hoyer's medium (Martin and Alexopoulos 1969) under a Nikon Eclipse E-600 light microscope (LM) with Nomarski interference contrast and a Nikon DS-Fi1 digital camera head for photographs. Spore measurements of mature specimens were made under an oil immersion objective and include ornamentation. The number of measured spores $(S)$ is provided for each spore range. Values present in less than $3 \%$ of the measurements are given in parentheses. Collections and permanent slides of examined collections were deposited in MA-Fungi and KRAM.

The critical-point drying technique was used for scanning electron microscopy preparations. Specimens were examined with Hitachi S-3000N and Hitachi S-4700 scanning electron microscopes (SEMs) at 10-15 $\mathrm{kV}$. Scanning electron microscopy studies were made at the Scanning Electron Microscopy Services of the Royal Botanic Garden of Madrid and in the Laboratory of Field Emission Scanning Electron Microscopy and Microanalysis, Institute of Geological Sciences of the Jagiellonian University, Kraków. Terminology of spore 
ornamentation observed by scanning electron microscopy followed Rammeloo (1974).

\section{DNA extraction, PCR amplification, and} sequencing. - In order to verify the phylogenetic position of the species described in the present study and resolve taxonomic identity of Dianema collections, we performed molecular analyses based on two independently inherited genes: partial sequences of the nuc $18 \mathrm{~S}$ rDNA (18S) and partial sequences of elongation factor 1-alpha $(E F-1 \alpha)$. Sampling included all type species of genera of traditionally circumscribed Trichiales (Lado and Eliasson 2017), for which partial $18 S$ and $E F-1 \alpha$ were available. We included also Dictydiaethalium plumbeum (Schumach.) Rostaf., which according to the traditional system belongs to Cribrariaceae but was proved to have closer affinity to Trichiales (FioreDonno et al. 2013). Additionally, to resolve the taxonomic position of Dianema collections, we generated sequences for Dianema harveyi, the type species of the genus Dianema. Representative species of the genera Lycogala Adans. and Reticularia Bull. were used as outgroups (Fiore-Donno et al. 2013).

For some collections, the protocol based on direct polymerase chain reaction (PCR) method, as described by Janik et al. (2020), was applied; for others, total DNA was extracted from 4-6 adjacent sporocarps from each sample as described in Fiore-Donno et al. (2012). Samples in safelock Eppendorf tubes containing one 3-mm tungsten carbide bead were frozen at $-40 \mathrm{C}$ and then subjected to mechanical disruption in a TissueLyser II bead mill (Qiagen, Hilden, Germany). DNA extraction followed the DNeasy Plant Mini Kit protocol (Qiagen). For 18S, different primer pairs were employed, including $\mathrm{S} 1$ and SR4Bright from Fiore-Donno et al. (2013). Additionally, new specific primers for species of the order Trichiales were designed (all the sequences of the oligonucleotides are indicated in $5^{\prime} \rightarrow 3^{\prime}$ direction; $\mathrm{F}$ and $\mathrm{R}$ in names differentiate forward and reverse primers, respectively): SF01 (GGTTGATCCTGCCAGAATC) and SR01 (ACCAGACTTGTCCTCCAAT) (based on SR4Lyc in Fiore-Donno et al. 2013 with minor modifications). For $E F-1 \alpha$, a forward primer was also newly designed: EF03 (TGATCTACAAGTGCGGTG). Primer KEF_R3 published in Wrigley de Basanta et al. (2017) was employed as a reverse primer. PCR conditions were those described in Wrigley de Basanta et al. (2015) and Janik et al. (2020). Additionally, if amplification failed, a seminested PCR was conducted using newly designed SF02 (TCATATGCTTGTCCCGAAG) and EF04 (TGGGTGT TGGACAAACTC) as forward primers for $18 \mathrm{~S}$ and $E F-$
$1 \alpha$, respectively, in a total volume of $20 \mu \mathrm{l}$ containing: $1 \times$ AccuTaq LA Buffer (Sigma-Aldrich, St. Louis, Missouri), $0.5 \mathrm{mM}$ of each dNTPs, $0.4 \mu \mathrm{M}$ of each primer, $0.1 \%$ bovine serum albumin, 0.05 U REDAccuTaq LA DNA Polymerase (Sigma-Aldrich), and $1 \mu \mathrm{L}$ of purified product from the first PCR adjusted with double-distilled water $\left(\mathrm{ddH}_{2} \mathrm{O}\right)$, with the following cycling conditions: initial denaturation for $30 \mathrm{~s}$ at $96 \mathrm{C}$, followed by 35 cycles of $1 \mathrm{~min}$ at $94 \mathrm{C}, 45 \mathrm{~s}$ at $52 \mathrm{C}$, and $10 \mathrm{~min}$ at $68 \mathrm{C}$, and final elongation for $30 \mathrm{~min}$ at $72 \mathrm{C}$. Forward and reverse directions of each region were amplified and analyzed with an ABI 3730XL automated sequencer (Macrogen, Seoul, South Korea) or with an ABI 3500 sequencer (Applied Biosystems, Foster City, California) at the W. Szafer Institute of Botany, Polish Academy of Sciences.

Assembly and alignment.-Forward and reverse amplifications were assembled in Geneious Prime 2019.0.3. Additional sequences were retrieved from GenBank, with both $18 S$ and EF-1 $\alpha$ regions obtained from the same specimens (SUPPLEMENTARY TABLE 1). EF-1 $\alpha$ sequences, together with those retrieved from GenBank, were aligned with MAFFT 7 using the iterative refinement method (L-INS-i) and default parameters (Katoh and Standley 2013). Introns were detected and removed from the data set for the posterior phylogenetic analyses. The same process was followed to align the $18 \mathrm{~S}$ sequences together with a reference-masked alignment (function "add" in MAFFT), provided by Anna-Maria Fiore-Donno (Univeristy of Cologne, Germany), including sequences obtained from the same specimens as those of the EF- $1 \alpha$ data set. Due to the presence of introns and highly variable positions in the $18 \mathrm{~S}$ region, positions not included under the mask were removed from the data set prior to phylogenetic analyses. Because no incongruences were detected between these two regions, a third data set consisting of the concatenation of the EF-1 $\alpha$ and the $18 \mathrm{~S}$ regions was created and also analyzed. Additionally, an alignment data set with an extra $E F-1 \alpha$ sequence (KRAM M-1746) was created in order to include the whole diversity found within Dianema. Alignments and phylogenetic trees are available at TreeBASE (S25923).

Phylogenetic analyses. - For the three data sets, maximum likelihood (ML) analyses were conducted using IQ-TREE (Nguyen et al. 2015). Best substitution models were selected with ModelFinder (Kalyaanamoorthy et al. 2017) under the Bayesian information criterion (BIC). The EF- $1 \alpha$ data set was partitioned into three data blocks, one for each codon position. The concatenated data set was also partitioned, considering the same three 
Table 1. List of localities where collections representing the order Trichiales treated in this study were found (black circles in FIG. 1).

\begin{tabular}{|c|c|}
\hline Locality no. & Details of the locality \\
\hline ARG-07-01 & 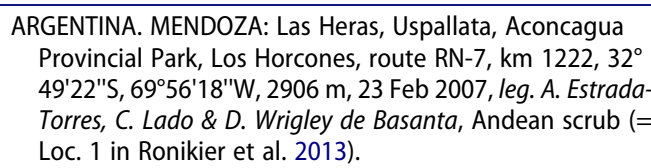 \\
\hline ARG-07-02 & $\begin{array}{l}\text { ARGENTINA. MENDOZA: Lujan de Cuyo, Uspallata, Volcán } \\
\text { Tupungato Provincial Park, Las Cuevas, old route RN-7 to } \\
\text { Cristo Redentor, } 32^{\circ} 48^{\prime} 41^{\prime \prime} \text {, } 70^{\circ} 04^{\prime} 33^{\prime \prime W}, 3479 \mathrm{~m}, 23 \\
\text { Feb 2007, leg. A. Estrada-Torres, C. Lado \& D. Wrigley de } \\
\text { Basanta, Andean scrub (= Loc. } 2 \text { in Ronikier et al. 2013). }\end{array}$ \\
\hline ARG-07-04 & $\begin{array}{l}\text { ARGENTINA. MENDOZA: Las Heras, Uspallata, Aconcagua } \\
\text { Provincial Park, Puente del Inca, route RN-7, km 1216, } 32^{\circ} \\
49^{\prime} 38^{\prime \prime S}, 69^{\circ} 53^{\prime} 08 " W, 2676 \text { m, } 23 \text { Feb 2007, leg. A. Estrada- } \\
\text { Torres, C. Lado \& D. Wrigley de Basanta, Andean scrub. }\end{array}$ \\
\hline ARG-07-22 & $\begin{array}{l}\text { ARGENTINA. MENDOZA: San Rafael, El Sosneado, Minas de } \\
\text { Azufre, route RP-220, } 74 \mathrm{~km} \text { NW from El Sosneado, by } \\
\text { Atuel River, 34 } 44^{\circ} 50^{\prime \prime} \text {, } 70^{\circ} 05^{\prime} 35^{\prime W}, 2257 \mathrm{~m}, 2 \text { Mar 2007, } \\
\text { leg. A. Estrada-Torres, C. Lado \& D. Wrigley de Basanta, } \\
\text { Andean grassland (= Loc. } 4 \text { in Ronikier et al. 2013). }\end{array}$ \\
\hline ARG-07-37 & $\begin{array}{l}\text { ARGENTINA. MENDOZA: Malargüe, Los Molles, Las Leñas, } \\
\text { Portezuelo Anchoa, } 12 \mathrm{~km} \text { by the track to Valle Hermoso, } \\
35^{\circ} 05^{\prime} 499^{\prime \prime} \text {, } 70^{\circ} 08^{\prime} 20^{\prime \prime W}, 2805 \mathrm{~m}, 5 \mathrm{Mar} 2007 \text {, A. Estrada- } \\
\text { Torres, C. Lado \& D. Wrigley de Basanta, Andean grassland } \\
\text { (= Loc. 5a in Ronikier et al. 2013). }\end{array}$ \\
\hline ARG-07-38 & $\begin{array}{l}\text { ARGENTINA. MENDOZA: Malargüe, Los Molles, Las Leñas, } \\
\text { Virgen de los Arrieros, } 10 \mathrm{~km} \text { W from Las Leñas on the } \\
\text { track to Valle Hermoso, } 35^{\circ} 05^{\prime} 29^{\prime \prime S}, 70^{\circ} 07^{\prime} 32^{\prime \prime W}, 2715 \mathrm{~m} \text {, } \\
5 \text { Mar 2007, leg. A. Estrada-Torres, C. Lado \& D. Wrigley de } \\
\text { Basanta, Andean grassland (= Loc. } 6 \text { in Ronikier et al. } \\
\text { 2013). }\end{array}$ \\
\hline ARG-07-72 & $\begin{array}{l}\text { ARGENTINA. MENDOZA: Las Heras, Uspallata, Los } \\
\text { Penitentes, route RN-7, km 1211, 32 } 50^{\circ} 29^{\prime \prime} S, 69^{\circ} 49^{\prime} 50^{\prime \prime} \text {, } \\
2600 \mathrm{~m}, 11 \text { Mar 2007, leg. A. Estrada-Torres, C. Lado \& } \\
\text { D. Wrigley de Basanta, Andean scrub (= Loc. } 7 \text { in Ronikier } \\
\text { et al. 2013). }\end{array}$ \\
\hline ARG-07-73 & $\begin{array}{l}\text { Argentina. MENDOZA: Las Heras, Uspallata, Los Penitentes, } \\
\text { route RN-7, km 1213, Santa María River, 3250'13"S, } 69^{\circ} \\
51^{\prime} 21 " W, 2625 \mathrm{~m}, 11 \text { Mar 2007, leg. A. Estrada-Torres, } \\
\text { C. Lado \& D. Wrigley de Basanta, Andean scrub. }\end{array}$ \\
\hline ARG-08-08 & $\begin{array}{l}\text { ARGENTINA. MENDOZA: San Carlos, Laguna del Diamante } \\
\text { Nature Reserve, } 6 \text { km W of Refugio General Alvarado, } 34^{\circ} \\
\text { 13'29"S, 69²6'20"W, } 2875 \text { m, } 24 \text { Feb 2008, leg. A. Estrada- } \\
\text { Torres, E. García, C. Lado \& D. Wrigley de Basanta, Andean } \\
\text { scrub (= Loc. } 8 \text { in Ronikier et al. 2013). }\end{array}$ \\
\hline ARG-08-11 & $\begin{array}{l}\text { ARGENTINA. MENDOZA: Malargüe, Los Molles, Las Leñas, } \\
\text { Portezuelo Ancho, } 12 \mathrm{~km} \text { on the track to Valle Hermoso, } \\
35^{\circ} 05^{\prime} 48^{\prime \prime} \mathrm{S}, 70^{\circ} 08^{\prime} 17^{\prime \prime W}, 2789 \mathrm{~m}, 25 \mathrm{Feb} 2008 \text {, leg. } \\
\text { A. Estrada-Torres, E. García, C. Lado \& D. Wrigley de } \\
\text { Basanta, steppe shrubland, near melting snow patches. }\end{array}$ \\
\hline ARG-08-36 & $\begin{array}{l}\text { ARGENTINA. MENDOZA: Las Heras, Uspallata, Aconcagua } \\
\text { Provincial Park, Los Horcones, route RN-7, km 1222, } 32^{\circ} \\
49^{\prime} 21 " \text { "S, 69 } 69^{\circ} 19 " W, 2852 \text { m, } 28 \text { Feb 2008, leg. A. Estrada- } \\
\text { Torres, E. García, C. Lado \& D. Wrigley de Basanta, Andean } \\
\text { scrub. }\end{array}$ \\
\hline ARG-08-37 & $\begin{array}{l}\text { ARGENTINA. MENDOZA: Lujan de Cuyo, Uspallata, volcán } \\
\text { Tupungato Provincial Park, Las Cuevas, old route RN-7 to } \\
\text { Cristo Redentor, } 32^{\circ} 48^{\prime} 54^{\prime \prime}, 70^{\circ} 04^{\prime} 27^{\prime \prime} \text {, } 3524 \text { m, } 29 \\
\text { Feb } 2008 \text {, leg. A. Estrada-Torres, E. García, C. Lado \& } \\
\text { D. Wrigley de Basanta, Andean scrub, near melting snow } \\
\text { patches. }\end{array}$ \\
\hline ARG-08-38 & $\begin{array}{l}\text { ARGENTINA. MENDOZA: Lujan de Cuyo, Uspallata, volcán } \\
\text { Tupungato Provincial Park, Las Cuevas, Quebrada del } \\
\text { Navarro, route RN-7, km 1233, } 32^{\circ} 48^{\prime} 38^{\prime \prime} \text { S, } 70^{\circ} 04^{\prime} 09 " W \text {, } \\
3301 \mathrm{~m} \text {, } 29 \text { Feb 2008, leg. A. Estrada-Torres, E. García, } \\
\text { C. Lado \& D. Wrigley de Basanta, Andean scrub. }\end{array}$ \\
\hline
\end{tabular}

(Continued)
Table 1. (Continued).

\begin{tabular}{|c|c|}
\hline Locality no. & Details of the locality \\
\hline ARG-08-40 & $\begin{array}{l}\text { ARGENTINA. MENDOZA: Las Heras, Uspallata, Los } \\
\text { Penitentes, route RN-7, km } 1211,32^{\circ} 50^{\prime} 30^{\prime \prime S}, 69^{\circ} 49^{\prime} 54^{\prime \prime W}, \\
2594 \mathrm{~m}, 1 \text { Mar 2008, leg. A. Estrada-Torres, E. García, } \\
\text { C. Lado \& D. Wrigley de Basanta, low shrubs and Andean } \\
\text { cushion vegetation (= Loc. } 9 \text { in Ronikier et al. 2013). }\end{array}$ \\
\hline ARG-09-16 & $\begin{array}{l}\text { ARGENTINA. NEUQUÉN: Ñorquin, Andacoyo, Moncol, Puerto } \\
\text { Pichachén, route 57, } 17 \mathrm{~km} \text { Southwest of the National } \\
\text { Guard post, } 37^{\circ} 26^{\prime} 51^{\prime} \mathrm{S}, 71^{\circ} 05^{\prime} 57^{\prime \prime W}, 1930 \mathrm{~m}, 8 \text { Nov } 2009, \\
\text { leg. A. Estrada-Torres, E. García, C. Lado, A. Ronikier \& } \\
\text { D. Wrigley de Basanta, Andean scrub and "krummholz" } \\
\text { forms of Nothofagus sp., near melting snow patches. }\end{array}$ \\
\hline ARG-09-17 & $\begin{array}{l}\text { ARGENTINA. NEUQUÉN: Ñorquin, Andacoyo, Moncol, Puerto } \\
\text { Pichachén, route } 57,16 \mathrm{~km} \text { Southwest of police station, } \\
37^{\circ} 26^{\prime} 49^{\prime \prime} \mathrm{S}, 71^{\circ} 06^{\prime} 18^{\prime \prime} \mathrm{W}, 1880 \mathrm{~m}, 8 \text { Nov } 2009 \text {, leg. } \\
\text { A. Estrada-Torres, E. García, C. Lado, A. Ronikier \& } \\
\text { D. Wrigley de Basanta, Andean scrub and "krummholz" } \\
\text { forms of Nothofagus sp., near melting snow patches. }\end{array}$ \\
\hline ARG-09-62 & $\begin{array}{l}\text { ARGENTINA. RíO NEGRO: Bariloche, San Carlos de Bariloche, } \\
\text { Nahuel Huapi National Park, Villa Cerro Catedral ski } \\
\text { resort, } 41^{\circ} 09^{\prime} 49^{\prime \prime} S, 71^{\circ} 27^{\prime} 34^{\prime \prime W}, 1364 \mathrm{~m}, 21 \text { Nov } 2009 \text {, leg. } \\
\text { A. Estrada-Torres, E. García, C. Lado, A. Ronikier \& } \\
\text { D. Wrigley de Basanta, Nothofagus pumilio forest, near } \\
\text { melting snow patches. }\end{array}$ \\
\hline ARG-09-63 & $\begin{array}{l}\text { ARGENTINA. RíO NEGRO: Bariloche, San Carlos de Bariloche, } \\
\text { Nahuel Huapi National Park, Challhuaco, Neumeyer } \\
\text { shelter, } 41^{\circ} 15^{\prime} 33^{\prime \prime S}, 71^{\circ} 17^{\prime} 31^{\prime \prime W}, 1438 \mathrm{~m}, 22 \text { Nov } 2009, \\
\text { leg. A. Estrada-Torres, E. García, C. Lado, A. Ronikier \& } \\
\text { D. Wrigley de Basanta, Nothofagus pumilio forest, near } \\
\text { melting snow patches. }\end{array}$ \\
\hline
\end{tabular}

$E F-1 \alpha$ data blocks and an additional data block for the $18 \mathrm{~S}$ region. For each partition, model parameters were estimated independently with edge-linked branch lengths and the best partition scheme was selected using the "greedy" search algorithm (Chernomor et al. 2016) as implemented in IQ-TREE. Node supports were assessed with 1000 nonparametric bootstrap replicates.

Tree topologies and node supports were also evaluated with a Bayesian inference (BI) approach using MrBayes 3.2.7a (Ronquist et al. 2012). The same partitions and partition schemes as those of the ML analyses were considered. Markov chain Monte Carlo (MCMC) settings consisted of four independent runs, with four chains for each run and 20000000 generations. Trees were sampled every 1000 generations; the first $25 \%$ was discarded as burn-in. Substitution models were selected with the reversible-jump MCMC method (Huelsenbeck 2004). Among-site rate variations were established according to the ML results, considering a proportion of invariable sites and a rate for the remaining sites drawn from a gamma distribution $(+\mathrm{I}+\mathrm{G})$. The only exception to this setting was the second data block of the EF- $1 \alpha$ data set, where only gamma-distributed rates across sites were considered $(+\mathrm{I})$. Posterior probabilities 


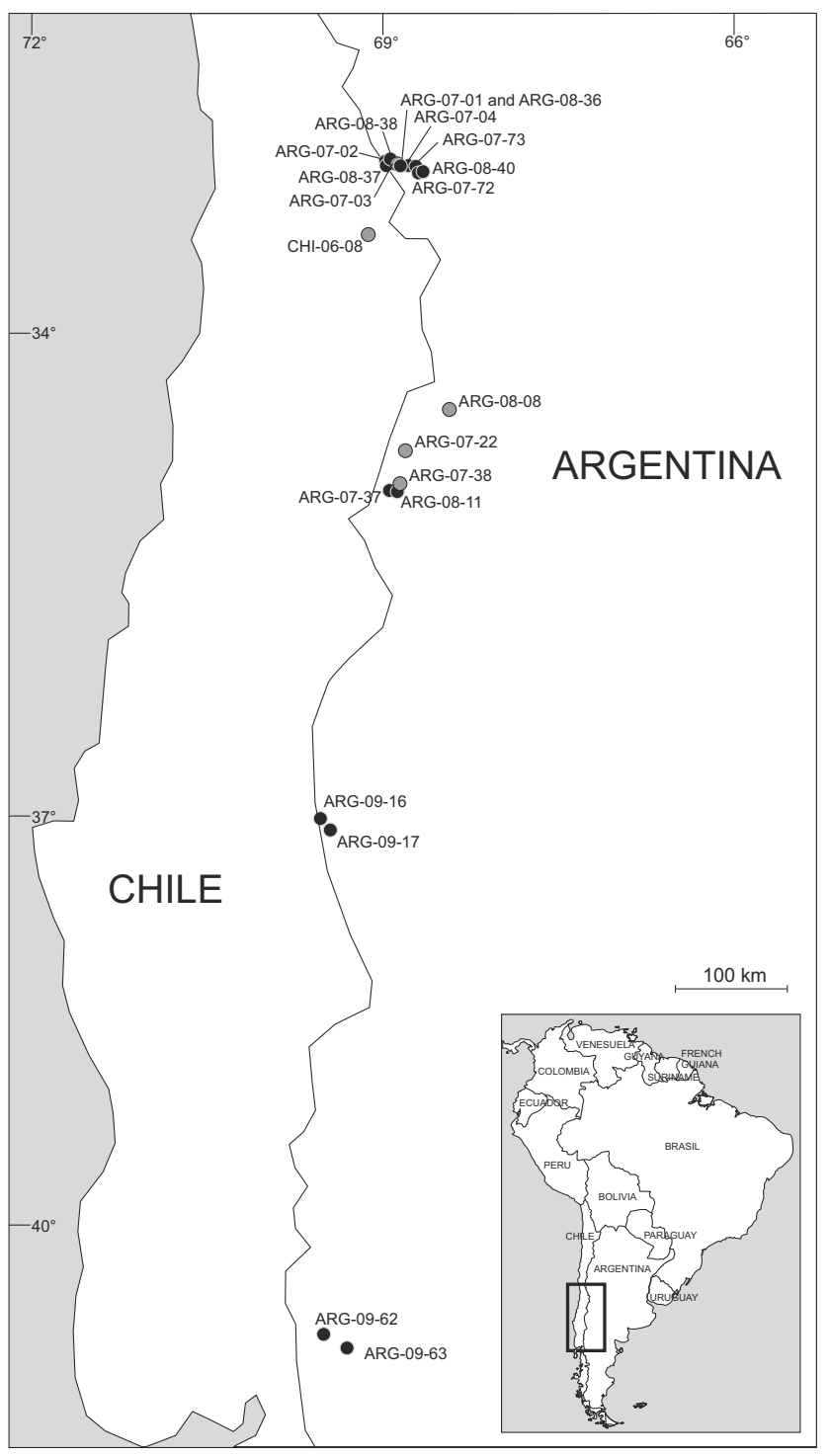

Figure 1. The study area. Black circles = localities on which the collections of the order Trichiales presented here were found (for explanation, see TABLE 1); gray circles = localities on which previously reported collections of the order Trichiales were found (Perichaena megaspora; Ronikier et al. 2013) and a new locality of $P$. megaspora from Chile (CHI-06-08).

were calculated with the MCMC method by sampling trees (Larget and Simon 1999; Huelsenbeck and Ronquist 2001). Convergence of the different runs was evaluated with TRACER 1.7.1 (Rambaut et al. 2018).

\section{RESULTS}

In total, 173 collections representing the order Trichiales were found at 19 sites. Twenty-two specimens represent Perichaena megaspora, which have already been studied by Ronikier et al. (2013); we add herein four specimens of that species. Forty-seven collections were damaged, too scanty, or not well developed, so they were excluded from the taxonomic part of the present study. The remaining 104 collections originated from 18 localities, listed in TABLE 1 and shown in FIG. 1. Additionally, during examination of the material of Physarales T. Macbr. (Ronikier and Lado, unpubl. data), we found one specimen of Perichaena megaspora from Chile, so we included it here, since it is the first report of the species from the country (locality CHI-06-08 in FIG. 1).

Fifteen species were recognized in the studied material. Two new species are proposed here: Hemitrichia crassifila, sp. nov., and Perichaena patagonica, sp. nov. Two morphotypes of Dianema, Dianema sp. 1 and Dianema sp. 2, were phylogenetically distinct, but due to insufficient data we did not propose them as new species. Four species, Dianema subretisporum, Trichia nivicola, T. sordida, and T. contorta var. karstenii (Rostaf.) Ing, were reported for the first time from the SH, whereas one species, Trichia alpina, was reported as new for Argentina. The species are listed alphabetically below, with comments for previously described species and descriptions and comments of the new species within the context of morphological diversity of South American collections and geographic distributions in the $\mathrm{SH}$.

We generated 23 new sequences representing nine species (FIG. 2, SUPPLEMENTARY TABLE 1, SUPPLEMENTARY FIG. 1), including type specimens of the newly described species, $H$. crassifila (MA-Fungi 91880) and P. patagonica (MA-Fungi 91906). All sequences were deposited in GenBank, under accession numbers MT154017-MT154038 (18S) and MT162156MT162177 (EF-1 $\alpha$ ). After removing uncertain alignment positions, the $18 \mathrm{~S}$ data set comprised a total of 374 positions and 46 sequences. The best substitution model selected was the TIM3e considering a proportion of invariable sites and a rate for the remaining sites drawn from a gamma distribution $(+\mathrm{I}+\mathrm{G})$. The length of the $E F$ $1 \alpha$ alignment was 1017 positions after the removal of introns. For the three data blocks partitioned, the selected models and the among-site rate variations were TIM3+I $+\mathrm{G}$ (position 1 in the codons), JC+I+G (position 2), and TIM2+G (position 3). ModelFinder also estimated these same results when considering the concatenated data set. The best partition scheme for the EF-1 $\alpha$ data set was considering each partition independently. Concerning the concatenated data set, an additional independent partition was established (that corresponding to the $18 \mathrm{~S}$ data block). Since no incongruences were detected among the trees obtained with the three different data sets, the phylogenetic tree resulting from the concatenated data set was presented (FIG. 2).

All specimens of the new species, Hemitrichia crassifila, clustered together in a clade with maximum support (100/1), and they phylogenetically differ from the morphologically similar species, $H$. intorta. These two species 


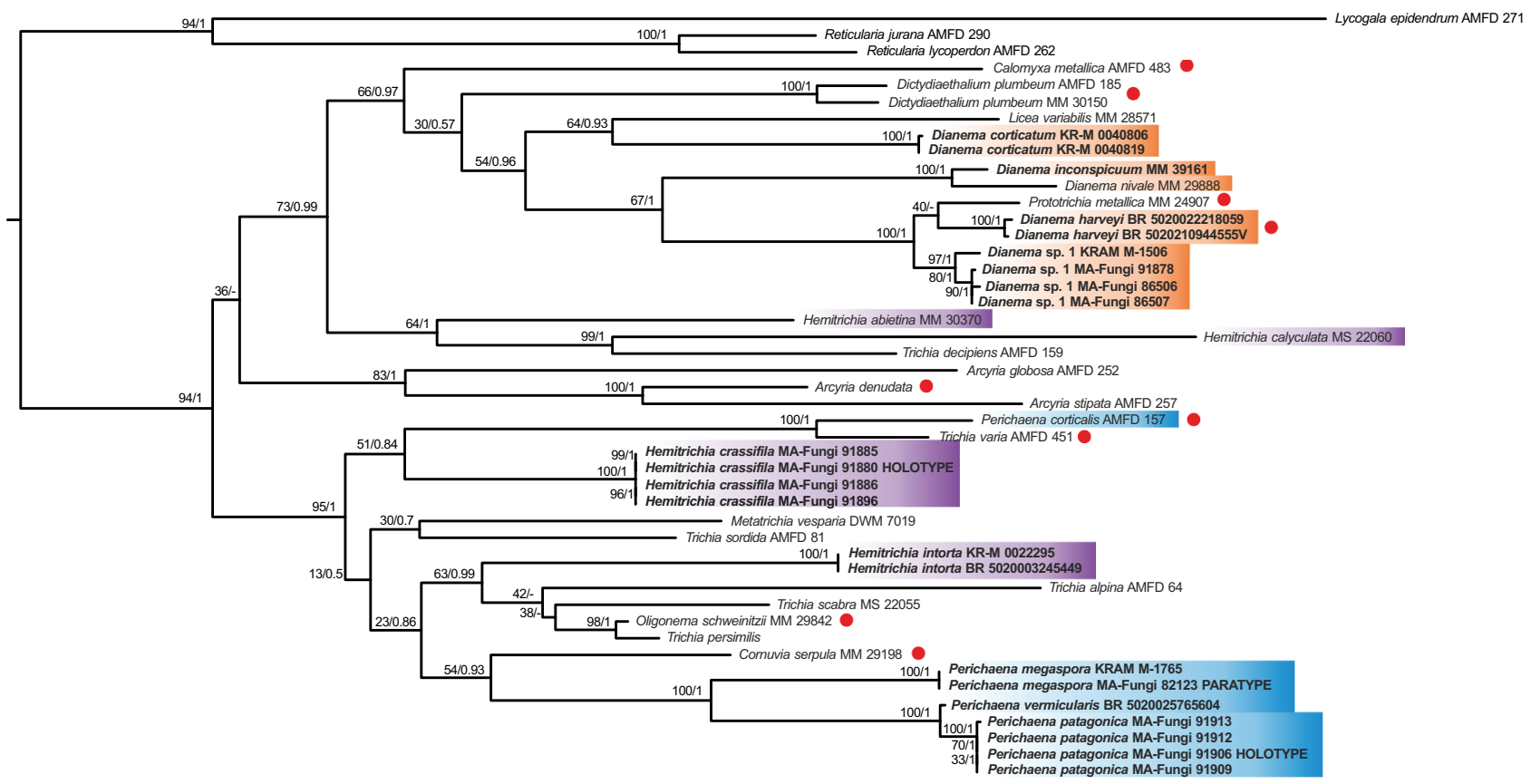

Figure 2. Phylogenetic tree inferred by maximum likelihood analysis of the concatenation of both $18 \mathrm{~S}$ and EF-1a alignments (1391 bp, 46 sequences). Species from the genera Lycogala and Reticularia (Reticulariaceae, Cribrariales) were used as outgroups. Nonparametric bootstrap values and Bayesian posterior probabilities are indicated above each branch respectively. Dashes indicate clades not recovered by the $\mathrm{Bl}$ analysis. Genera of interest in this study are highlighted in different colors. Sequences obtained during this study are indicated in bold. Red dots tag the type species of genera. The scale bar represents mean number of nucleotide substitutions per site.

diverged substantially from the other Hemitrichia species included, $H$. abietina (Wigand) G. Lister and H. calyculata (Speg.) M. L. Farr, which formed a separate clade with Trichia decipiens (Pers.) T. Macbr. (64/1). Specimens of Perichaena patagonica also clustered together in a clade with full support (100/1). This species is closely related to $P$. vermicularis (Schwein.) Rostaf. (100/1), and both are closely related to P. megaspora (100/1). The phylogenetic position of this group of species is distant regarding the position of the type species of the genus Perichaena, $P$. corticalis, which seemed to be more phylogenetically related to Trichia varia (Pers. ex J.F. Gmel.) Pers. (100/1), the type species of the genus Trichia. The species Dianema harveyi and Prototrichia metallica (Berk.) Massee were closely related to those specimens determined as Dianema sp. 1 (100/1), which grouped all together in an emergent clade (97/1). Other nivicolous species of the genus Dianema, D. inconspicuum and D. nivale, formed a sister clade with this PrototrichiaDianema group (67/1). European specimens of $D$. corticatum form a separate clade with the species Licea variabilis Schrad., although it was poorly supported (64/0.93). From the Dianema sp. 2 specimen (KRAM

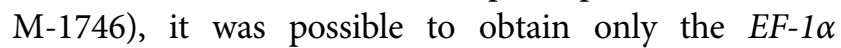

sequence. It showed a greater variability when compared with the rest of morphologically similar Dianema samples. In the phylogenetic tree including only specimens with the EF-1 $\alpha$ region (SUPPLEMENTARY FIG. 1), this specimen diverged as a sister taxon from the group formed by $P$. metallica, D. harveyi, and the rest of the specimens labeled as Dianema sp. 1 (95/1).

\section{TAXONOMY}

Dianema depressum (Lister) Lister, Monogr Mycetozoa, ed. 1:204. 1894.

FIG. 3

三Cornuvia depressa Lister, J Bot 29:264. 1891.

Description: Sporophores in small groups, pulvinate or hemispheric, gray-brown, sessile (FIG. 3A). Peridium inner side reticulate (FIG. 3D-E). Capillitium beige-colored, the capillitial threads clustered at ends and with a rough surface under LM, clearly reticulate under SEM (FIG. 3B). Spores beige-colored in mass (FIG. 3A), globose, $8.5-9(-9.5) \mu \mathrm{m}$ in total range, $9.0 \pm 0.2 \mu \mathrm{m}$ on average $\pm \mathrm{SD}(\mathrm{S}=30)$, about $3 / 4$ of the spore surface covered by a complete reticulum, the rest covered by an interrupted reticulum (FIG. 3C), like in other South American collections (Lado et al. 2014), the 

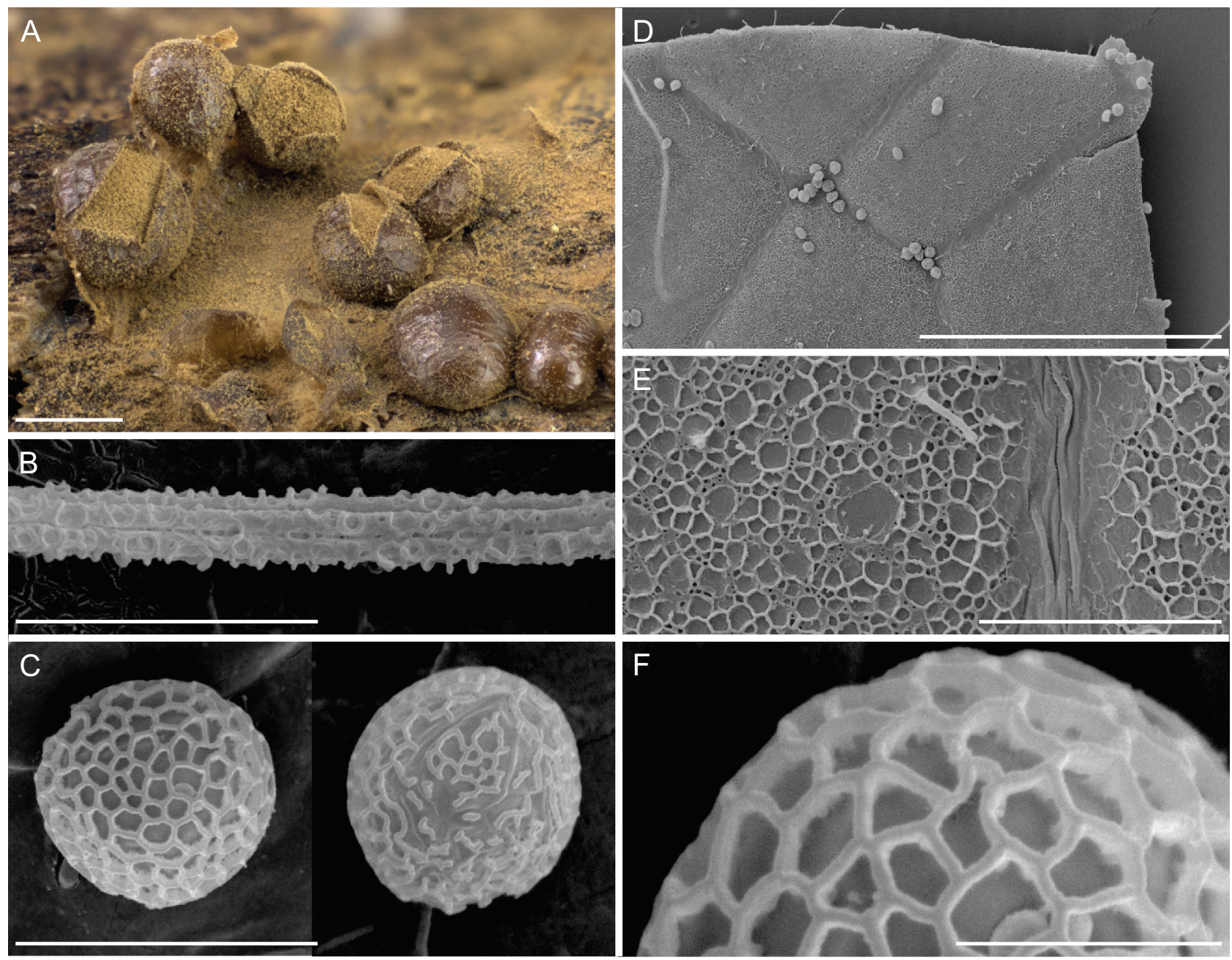

Figure 3. Dianema depressum (Lado 20767). A. Group of sporocarps. B. Capillitium (SEM). C. Spores covered by interrupted reticulum (SEM). D-E. Peridium inner surface (SEM). F. Details of spore ornamentation (SEM). Bars: $A=1 \mathrm{~mm} ; \mathrm{B}-\mathrm{C}=10 \mu \mathrm{m} ; \mathrm{D}=200 \mu \mathrm{m} ; \mathrm{E}=20$ $\mu \mathrm{m} ; \mathrm{F}=3 \mu \mathrm{m}$.

ornamentation appears reticulate type with perforated muri visible only under SEM (FIG. 3F).

Ecology and distribution: Cosmopolitan. Reported in the SH from Australia (Martin and Alexopoulos 1969), New Zealand (Rawson 1937; Mitchell 1992; Stephenson 2003), and South America in Chile, Argentina, and Paraguay (McHugh 2009; Lado et al. 2013, 2014). The species is not nivicolous (e.g., Poulain et al. 2011), occurring in winter months in Europe as a cold-period myxomycete (Chachuła et al. 2017). The Argentinian locality was typically nivicolous; thus, our record is the first report of this species occurring close to the melting snow cover in the mountains.

Specimen examined: ARGENTINA. ARG-09-63, on wood of Nothofagus pumilio, Lado 20767 (MA-Fungi 91874, duplicate in KRAM M-1503).

Other specimens examined: POLAND. Northwest part of the Beskid Śląski Mountains, Ustroń Commune, valley of the right-hand bank influent of the Jaszowiec stream valley, $49^{\circ} 42^{\prime} 22.5^{\prime \prime} \mathrm{N}, 18^{\circ} 50^{\prime} 51.9^{\prime \prime} \mathrm{E}$, ca. $450 \mathrm{~m}$, on beech branch, 2 Nov 2015, P. Chachuła \& M. Fiedor.

Comments: Dianema depressum is an easy to identify species due to a unique combination of the following characters: reticulate ornamentation of spores, capillitium and inner peridium surface, and capillitium threads clustered at ends. The Andean specimen is typical in all macro- and microscopic characters apart from sporocarp shape that is not distinctly depressed. For description of $\mathrm{NH}$ material, see Martin and Alexopoulos (1969), Neubert et al. (1993), Lado and Pando (1997), Poulain et al. (2011), and Chachuła et al. (2017).

Dianema subretisporum Kowalski, Mycologia 59:1080. 1968. FIG. 4

Description: Sporophores crowded in groups, sessile, pulvinate, up to $1 \mathrm{~mm}$ diam, rusty-colored (FIG. 4A). 

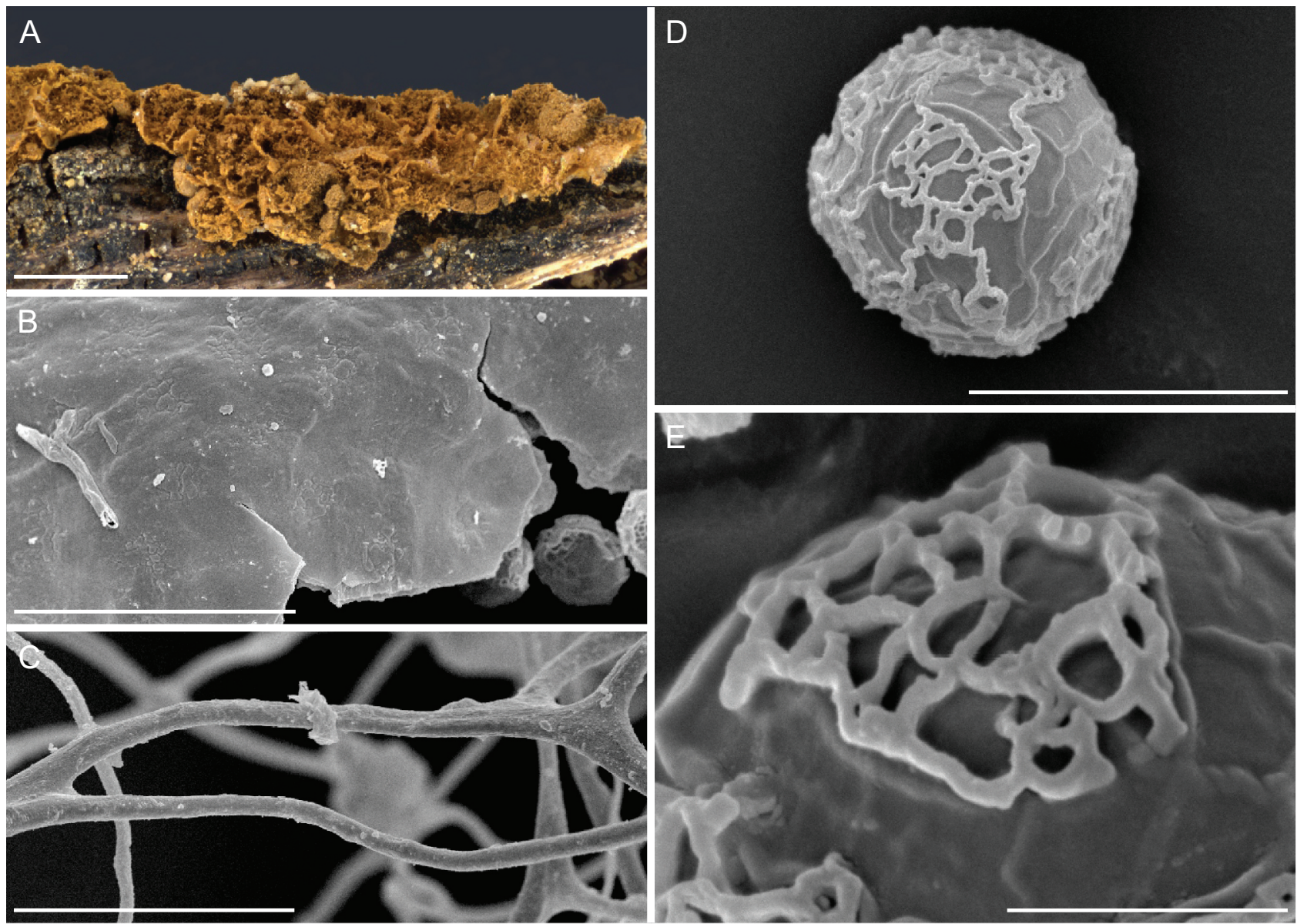

Figure 4. Dianema subretisporum (Lado 19258). A. Group of open sporocarps. B. Peridium inner surface (SEM). C. Capillitium (SEM). D. Spore (SEM). E. Details of spore ornamentation (SEM). Bars: $A=1 \mathrm{~mm} ; \mathrm{B}-\mathrm{C}=30 \mu \mathrm{m} ; \mathrm{D}=10 \mu \mathrm{m} ; \mathrm{E}=3 \mu \mathrm{m}$.

Peridium with green, violet, and golden reflections, double, brittle, opening irregularly, the inner side smooth under SEM (FIG. 4B). Capillitium a dense reticulum of rusty threads, attached to base of sporophore, threads smooth under SEM (FIG. 4C). Spores in mass rustycolored, yellow under LM, $10.5-13 \mu \mathrm{m}$ in total range, $11.6 \pm 0.7 \mu \mathrm{m}$ on average $\pm \mathrm{SD}(\mathrm{S}=30)$, covered with a fragmented reticulum (FIG. 4D-E).

Ecology and distribution: First record from the $\mathrm{SH}$ and South America. Strictly nivicolous, previously reported only from the NH: USA, France, and Russia (Kowalski 1968; Poulain et al. 2011; Novozhilov et al. 2013).

Specimen examined: ARGENTINA. ARG-08-11, on dead branches of a plant (Asteraceae), Lado 19258 (MAFungi 91879).

Comments: The South American specimen is typical in all macro- and micromorphological characters, and it perfectly fits the descriptions of the $\mathrm{NH}$ material that can be found in Kowalski (1968), Neubert et al. (1993), and Poulain et al. (2011).
Dianema sp. 1

FIG. 5

Description: Sporophores scattered or in groups of sessile, pulvinate to hemispheric, copper-brown sporocarps or short plasmodiocarps, $0.85-2.10 \mathrm{~mm}$ long, $0.75-1.70 \mathrm{~mm}$ wide, and $0.75-1.45 \mathrm{~mm}$ high $(\mathrm{n}=24)$ (FIG. 5A, D). Peridium slightly to strongly iridescent, single, dehiscing irregularly, the inner side smooth (FIG. 5B, E). Capillitium ochraceous to rusty-yellow, not dense, straight, rigid, buildup of parallel and dichotomously branched threads connecting the base of sporotheca and peridium; capillitial threads firmly attached to the peridium (FIG. 5E), mostly smooth, sometimes with scattered round swellings or one spiral line. Spores rustyyellow in mass, grouped in clusters of 2-6(-8) (FIG. 5C) or free (FIG. 5E, F). Spores in clusters elliptic, 10.5-13.5(-15) $\times$ $(8-) 9-12(-13) \mu \mathrm{m}$ in total range, $12.2 \pm 1.1 \times 10.1 \pm 1.1 \mu \mathrm{m}$ on average $\pm S D(S=60)$, covered by spines, at the place of contact the spines connect adjacent spores in a cluster. Free spores spherical, (10-)10.5-11.5(12) $\mu \mathrm{m}$ in total range, $11.0 \pm$ $0.4 \mu \mathrm{m}$ on average $\pm S D(S=120)$, covered by spines, baculate under SEM (FIG. 5C, F) 

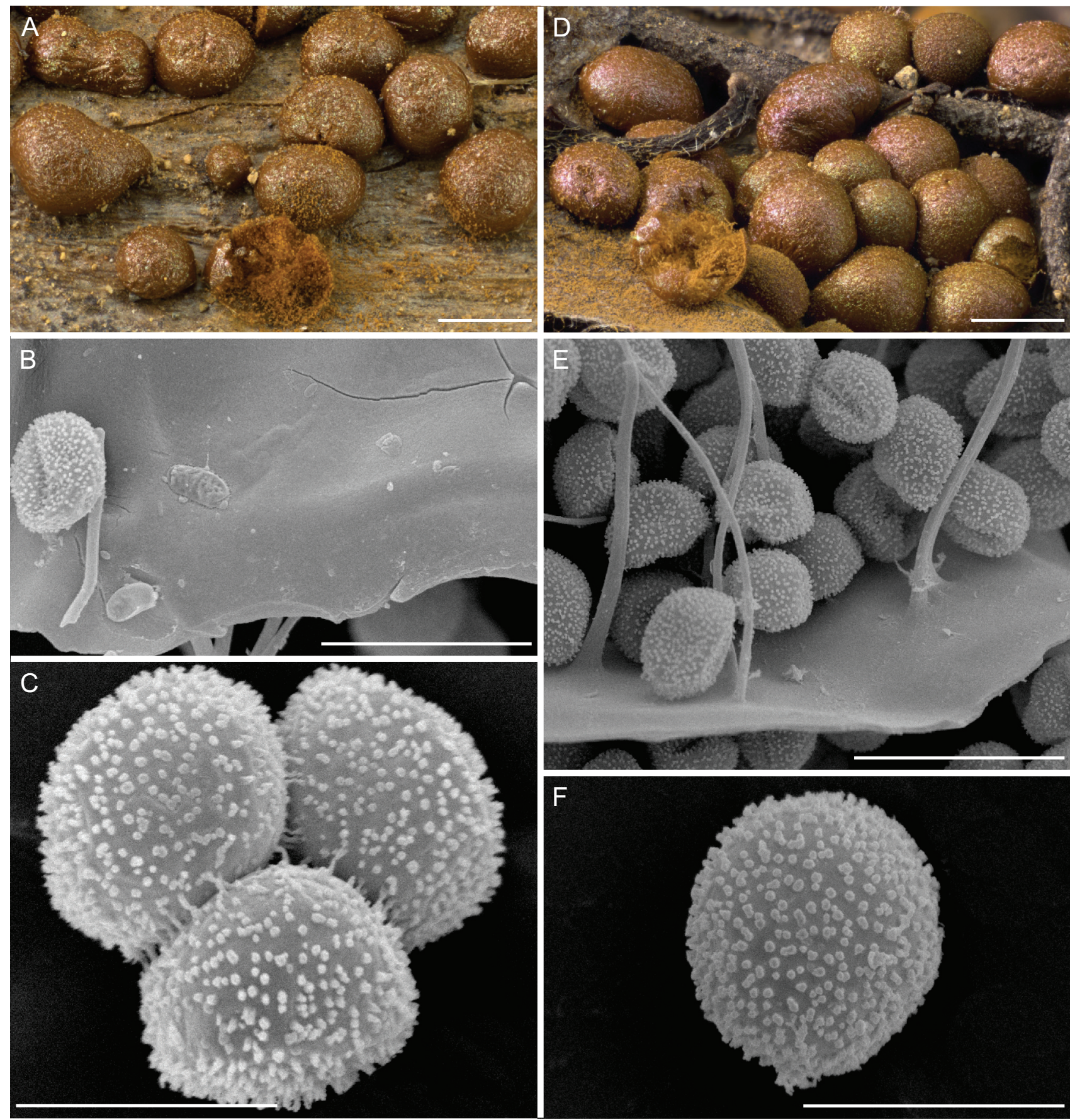

Figure 5. Dianema sp. 1. A, D. Group of sporocarps. B, E. Peridium inner surface (SEM). C, F. Spores (SEM). A-C. Lado 20692. D-F. Lado 20689. Bars: $A, D=1 \mathrm{~mm} ; B, E=20 \mu \mathrm{m} ; C, F=10 \mu \mathrm{m}$.

Ecology and distribution: Near melting snow patches, but in the phylogenetic analysis two nivicolous specimens cluster together with two other non-nivicolous specimens from South America (FIG. 2: MA_86506 and MA_86507); it is possible that this morphotype has wider ecological preferences.

Specimens examined: ARGENTINA. ARG-09-17, on branch of Nothofagus sp., Lado 20352 (MA-Fungi
91872), Lado 20389 (MA-Fungi 91877); ARG-09-62, on wood of Nothofagus sp., Lado 20692 (MA-Fungi 91873, duplicate in KRAM M-1506); on leaves of Nothofagus pumilio, Lado 20689 (MA-Fungi 91878).

Other specimens examined: Dianema corticatum Lister. SPAIN. HUESCA: San Juan de Plan, Viadós Millares Lake, $42^{\circ} 38^{\prime} 14^{\prime \prime} \mathrm{N}, 0^{\circ} 24^{\prime} 03^{\prime \prime} \mathrm{E}, 2300 \mathrm{~m}$, on trunk of Pinus nigra, 4 Jun 1996, Lado 8101 (MA-Fungi 73199). GERMANY. 
BADEN-WÜRTTEMBERG: Kreis Freudenstadt, Stadt-/ Gemeindeteil v. Baiersbronn, Ruhestein NSG "Wilder See-Hornisgrinde," near the western edge Fichten-/ Tannen-Mischwald der Karwand, standing dead trunk of Abies alba, decorticated, moderately decayed, 20 Sep 2013, M. Schnittler 27609, T. Hoppe (KR-M-0040806); standing dead trunk of Picea abies, decorticated, moderately decayed, 20 Sep 2013, M. Schnittler 27623, T. Hoppe (KRM-0040819). Dianema harveyi Rex. BELGIUM. NAMUR: Malonne, sur branche de tilleul, 7 Feb 1992, G. Thiry M824 (BR5020022218059); VLAAMS-BRABANT: Sint-PietersRode (Luttelkolen), randbosje Hortdomein, naakt hout op de grond, 31 Dec 2013, Jos Van Roy RLE/2014/1405 (BR5020210944555V). NETHERLANDS: N.E. NannengaBremekamp 2491 (BR5020052498216). USA. MAINE: F.L. Harvey (BPI 746311, BPI 746312, original material).

Comments: Dianema sp. 1 is particularly difficult to interpret based on morphology. The sporophores are grouped or scattered (FIG. 5A, D) and very similar in shape and color to Dianema harveyi and Prototrichia metallica, as illustrated by Poulain et al. (2011), and to other $\mathrm{NH}$ collections of Dianema harveyi, including the original material studied by us (see "Other specimen(s) examined"), whereas they are essentially different from the sporophores of Dianema corticatum, the only species of the genus with clustered spores. Molecular data confirm the close relationships of the two South American specimens with clustered (KRAM M-1506) and free (MA-Fungi 91878) spores (FIG. 2). The degree of firmness of adherence of spores differs between D. corticatum and Dianema sp. 1. Adjacent spores of $D$. corticatum are ornamented only at the outer spore surface (Martin and Alexopoulos 1969) and very closely appressed and difficult to separate (Demaree and Kowalski 1975), whereas the spores of Dianema sp. 1 seem to be connected by spine tips. This weak attachment may be the reason for which under some circumstances the spores become free. Dianema sp. 1 likely represents a new unknown South American species characterized by moslty sporocarpic appearance, single peridium, and spiny spores that can be free or clustered. More specimens have to be studied to confirm the range of morphological variability of this newly discovered morphotype.

\section{Dianema sp. 2}

FIG. 6

Description: Sessile, pulvinate, hemispheric or elongated, copper-brown sporocarps or plasmodiocarps, 1-6 mm long, $0.8-2.4 \mathrm{~mm}$ wide, and $0.75-1.70 \mathrm{~mm}$ high $(\mathrm{n}=11)$ (FIG. 6A). Peridium strongly iridescent,
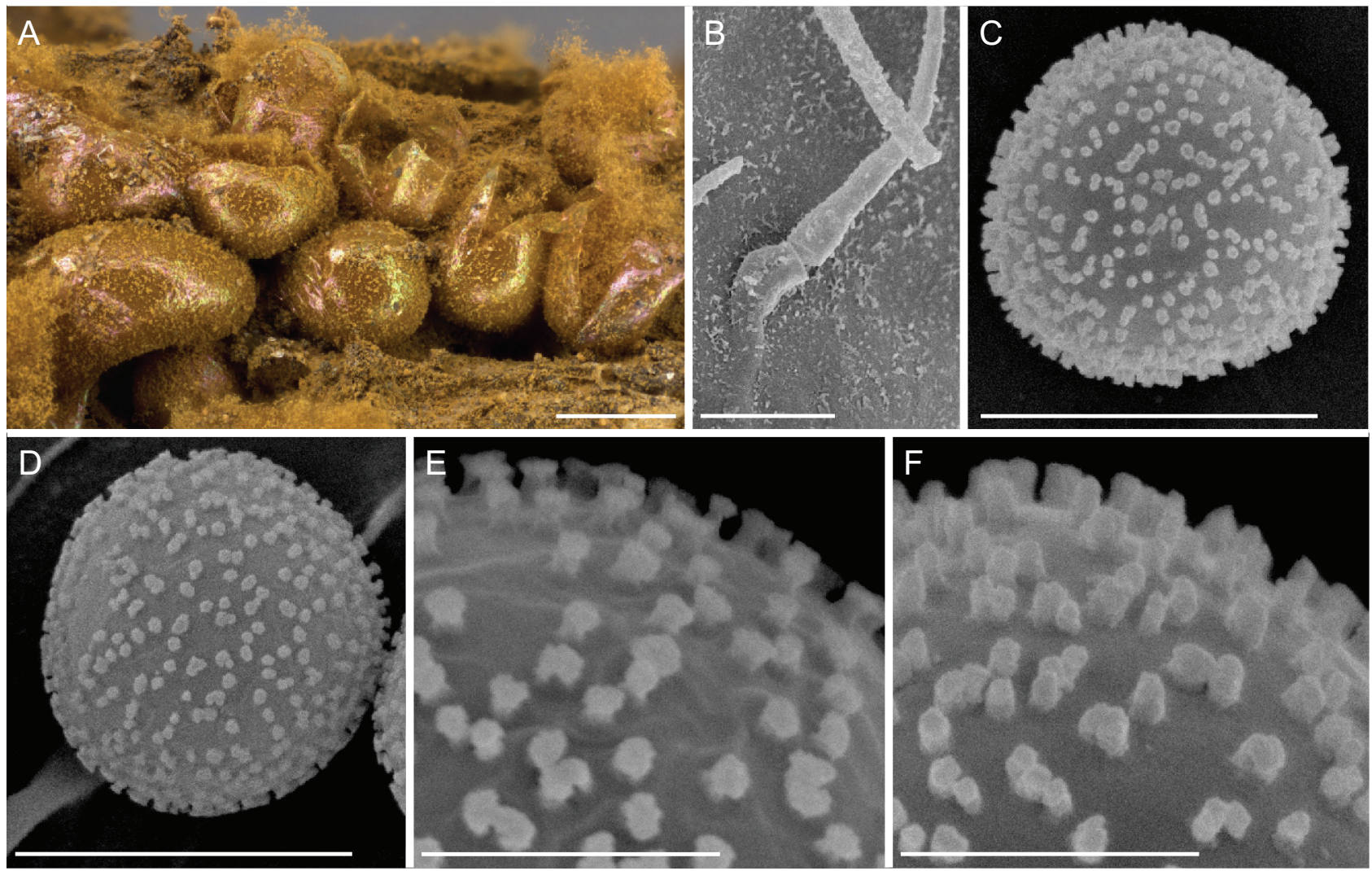

Figure 6. Dianema sp. 2. A. Group of sporocarps. B. Peridium inner surface with attached capillitium thread (SEM). C-D. Spores (SEM). E-F. Details of spore ornamentation (SEM). A-C, F. Lado 20367. D-E. Lado 20346. Bars: A = $1 \mathrm{~mm} ; \mathrm{B}-\mathrm{D}=10 \mu \mathrm{m} ; \mathrm{E}-\mathrm{F}=3 \mu \mathrm{m}$. 
thin, transparent, the inner side rough (FIG. 6B). Capillitium abundant, rusty-yellow, dense; capillitial threads equally thick over entire length, very long and flexuous sparsely branched, pale rusty-yellow under LM, smooth or with scattered round to broadly fusiform nodes, attached to peridium but easily detaching from it (FIG. 6A-B). Spores ochraceous in mass, very pale, almost hyaline under LM, 9-11 $\mu \mathrm{m}$ diam in total range, $9.9 \pm 0.5 \mu \mathrm{m}$ on average \pm SD $(S=60)$, densely covered with spines, baculate or pilate under SEM (FIG. 6C-F).

Ecology and distribution: Near melting snow patches in the austral Andes.

Specimens examined: ARGENTINA. ARG-09-17, on branch of Nothofagus sp., Lado 20346 (MA-Fungi 91875); on trunk of Nothofagus sp., Lado 20367 (MAFungi 91876, duplicate in KRAM M-1746).

Other specimen examined: Dianema nivale (Meyl.) G. Lister. SWITZERLAND. VAUD: Jura Mountains, Jous de Baulmes, $1250 \mathrm{~m}$, a bord de la neige, May 1910, Ch. Meylan (BPI 746316).

Comments: Macroscopically, Dianema sp. 2 resembles $D$. nivale but differs from it by the abundant elastic and flexuous capillitium not branched in a manner described by Meylan (1910) for D. nivale. The spore ornamentation is variable. One specimen has pilate spores under SEM (FIG. 6D-E), whereas the other collection has baculate spores (FIG. 6C, F). Our phylogenetic results show that one of the collections occupies a separate position in the EF-1 $\alpha$ phylogeny sister to the group formed by Prototrichia metallica, D. harveyi, and Dianema sp. 1 (SUPPLEMENTARY FIG. 1). Further specimens are needed to confirm the taxonomic affinity of this morphotype.

Hemitrichia crassifila A. Ronikier \& Lado, sp. nov.

FIGS. 7A-E, 8A-D

MycoBank MB834666

Etymology: crassifila (Latin), in reference to the remarkably thick capillitial threads.

Typification: ARGENTINA. MENDOZA: Uspallata, Puente del Inca, Aconcagua Provincial Park, route RN7, km 1216, 32 ${ }^{\circ} 4^{\prime} 38^{\prime \prime} \mathrm{S}, 69^{\circ} 53^{\prime} 08^{\prime \prime} \mathrm{W}, 2676$ m (ARG-0704), on dead branches of an Andean bush (Asteraceae), 23 Feb 2007, A. Estrada-Torres, C. Lado \& D. Wrigley de Basanta, Lado 18542 (holotype MA-Fungi 91880, isotype KRAM M-1747). GenBank: 18S = MT154030; EF$1 \alpha=$ MT162169.

Diagnosis: Sporocarps shortly stipitate, sporotheca olivaceous-yellow with blackish stalks, capillitium bright yellow; spores spiny, bright yellow in mass, (12-)13-17 $(-21) \mu \mathrm{m}$ diam; net-like capillitium composed of thick $(6-9 \mu \mathrm{m})$ spiny tubules with numerous branches and numerous spiny free ends. Nivicolous in mountains of South America.

Description: Sporophores sporocarpic, scattered, subsessile or shortly stipitate, total height 0.1-1.10(1.50) $\mathrm{mm}(\mathrm{n}=62)$ (FIG. 7A). Sporotheca globose to slightly subglobose, and then almost always slightly higher than wide, (0.35-)0.55-1.10(-1.80) mm diam $(\mathrm{n}=55)$, pale olivaceous-yellow to pale brownish-yellow, darker at base, paler toward apex, sometimes unevenly colored from remnants of refuse matter, surface dull or slightly shinning. Hypothallus inconspicuous. Stalk erect, short, 0.05-0.55(-0.75) $\mu \mathrm{m}$ long $(\mathrm{n}=62)$, dark brown to black. Peridium single, persistent, pale yellow to pale ochraceous-yellow under LM, outer surface covered with ochraceous-brown particles, inner surface covered with wrinkles and scattered papillae under SEM (FIG. 7B), dehiscence by irregular splitting. Capillitium dense, slightly expanding after the peridial dehiscence, bright yellow under reflected light, citrine-yellow under LM, composed of tubules 6-9 $\mu$ m thick $(\mathrm{n}=20)$, forming a net, with numerous branches and occasional swellings, the tubules covered by several irregular (branching and vanishing) spirals, with numerous spines and without stretch marks between spirals (FIGS. 7A, D, 8A, C), capillitial free ends numerous, slightly swollen and covered by several conspicuous spines 1-2 $\mu \mathrm{m}$ long (FIGS. 7E, 8B). Spores concolorous with capillitium, bright yellow in mass, citrine-yellow under LM, slightly paler, almost hyaline at one side, globose, (12-)13-17(-21) $\mu \mathrm{m}$ in total range, $14.8 \pm 1.4 \mu \mathrm{m}$ on average $\pm \mathrm{SD}(\mathrm{S}=657)$, spiny under LM, irregularly baculate under SEM, baculae loosely arranged, lower and isolated at one side, fusing into short and irregular subreticulum at another side (FIGS. 7C, 8D). Plasmodium unknown.

Ecology and distribution: Occurring after snow melt at high elevations, ca. 2600-3500 m, austral Andes, Argentina, late austral summer.

Additional specimens examined: ARGENTINA. ARG07-01, on dead trunk of an Andean bush, Lado 18492 (MA-Fungi 91881), Lado 18494 (MA-Fungi 91882), Lado 18497 (MA-Fungi 91883), Lado 18500 (MA-Fungi 91884), Lado 18502 (MA-Fungi 91885) (duplicate in KRAM M-1748); ARG-07-02, Lado 18507 (MA-Fungi 91886) (duplicate in KRAM M-1749); ARG-07-72, on dead branches of an Andean bush (Asteraceae), Lado 18746 (MA-Fungi 91887), on leaves and dead branches, Lado 18770 (MA-Fungi 91888) (duplicate in KRAM M-1750), on dead branches, Lado 18777 (MA-Fungi 91889), on leaves and dead branches of an Andean bush (Fabaceae), Lado 18786 (MA-Fungi 91890) (duplicate in KRAM M-1751); ARG-07-73, on dead branches of an Andean bush (Asteraceae), Lado 18798 (MA-Fungi 

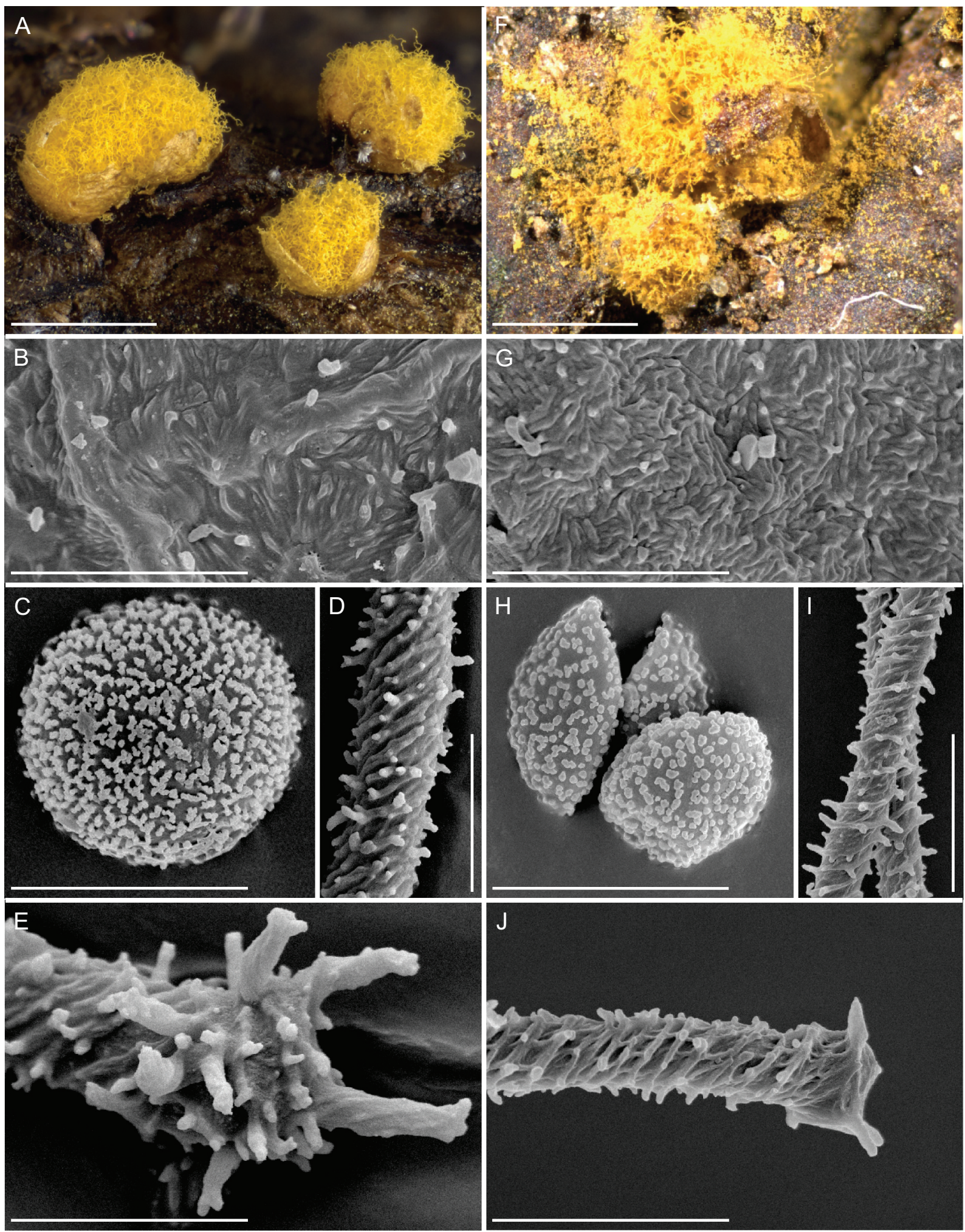

Figure 7. Comparison of Hemitrichia crassifila with H. intorta. A-E. H. crassifila. A. Group of open sporocarps (Lado 18542, holotype). B. Peridium inner surface (SEM) (Lado 18542, holotype). C. Spore (SEM) (Lado 18804). D. Fragment of capillitial thread covered with dense, irregular, spiny spirals, with no longitudinal striae visible between the spirals (SEM) (Lado 18542, holotype). E. Spiny capillitial end (SEM) (Lado 18542, holotype). F-J. H. intorta. F. Two open sporocarps (BPI 838683). G. Peridium inner surface (SEM) (BM001089127, lectotype). H. Spores (SEM) (BM001089127, lectotype). I. Fragments of capillitial threads covered with loose, regular, spiny spirals with visible longitudinal striae between them (SEM) (BM001089127, lectotype). J. Spiny capillitium end (SEM) (BM001089127, lectotype). Bars: $A, F=1 \mathrm{~mm} ; \mathrm{B}-\mathrm{E}, \mathrm{G}-\mathrm{J}=10 \mu \mathrm{m}$. 

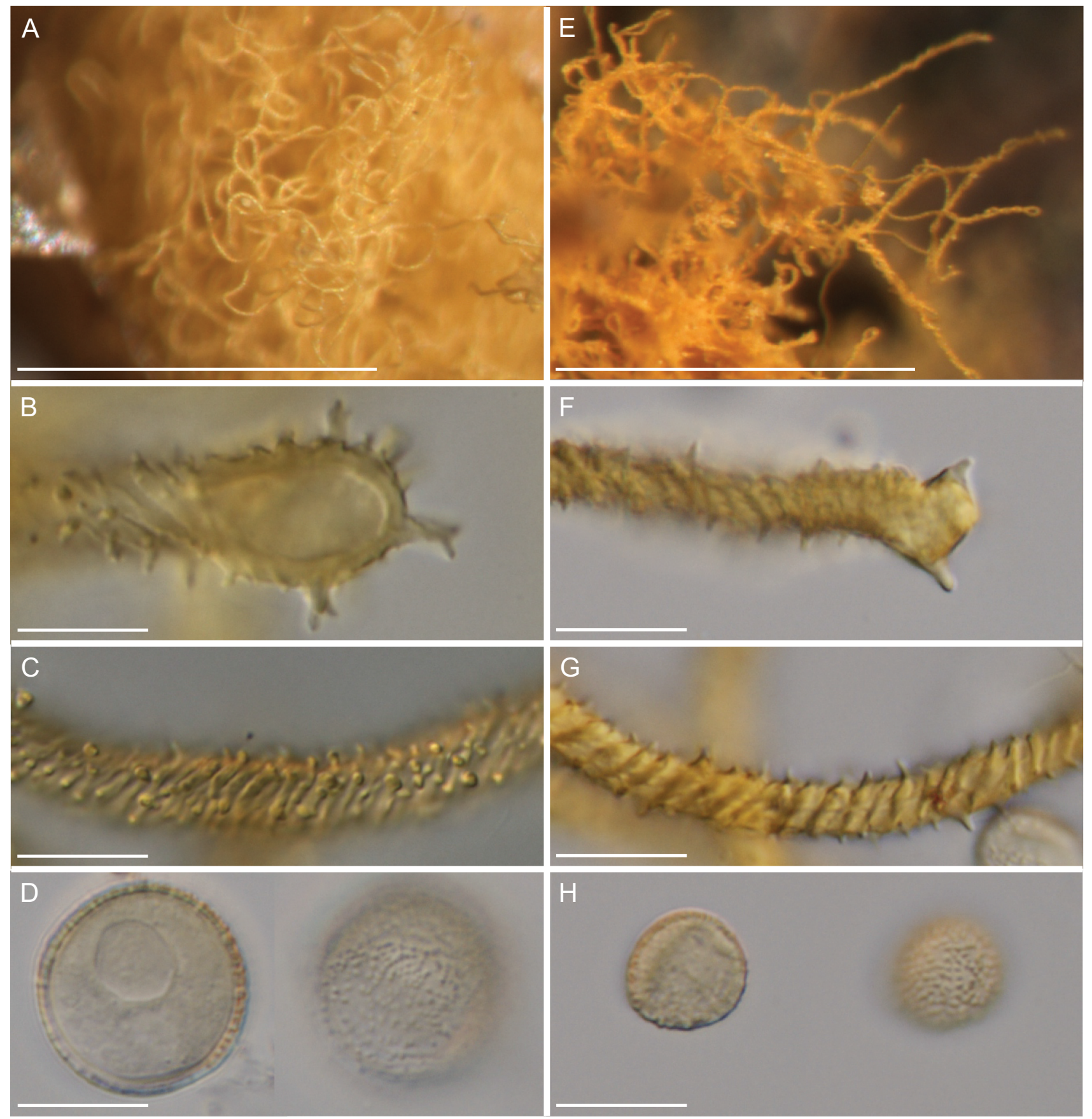

Figure 8. Comparison of Hemitrichia crassifila with H. intorta. A-D. H. crassifila. A. Capillitium forming a loose net (Lado 18804). B. Spiny capillitial end (LM) (Lado 18542, holotype). C. Fragment of capillitial thread covered with dense, irregular, spiny spirals, with no longitudinal striae visible between the spirals (LM) (Lado 18542, holotype). D. Spores (LM) (Lado 18804). E-H. H. intorta (BPI 838683). E. Capillitium forming numerous twisted loops. F. Spiny capillitial end (LM). G. Fragment of capillitial thread covered with loose, regular, spiny spirals with visible longitudinal striae between them (LM). H. Spores (LM). Bars: A, E $=0.5 \mathrm{~mm}$; B-D, $F-H=10 \mu \mathrm{m}$.

91891), Lado 18804 (MA-Fungi 91892) (duplicate in KRAM M-1752); ARG-08-36, on dead branches of a prostrate Andean bush, Lado 19516 (MA-Fungi 91893), Lado 19517 (MA-Fungi 91894); ARG-08-37, on branch of Adesmia sp., Lado 19523 (MA-Fungi 91895) (duplicate in KRAM M-1753); ARG-08-38, on branch of Adesmia sp., Lado 19527 (MA-Fungi 91896) (duplicate in
KRAM M-1754), Lado 19528 (MA-Fungi 91897), Lado 19529 (MA-Fungi 91898) (duplicate in KRAM M-1755), Lado 19532 (MA-Fungi 91899); ARG-08-40, on branch of Adesmia sp., Lado 19546 (MA-Fungi 91900), Lado 19549 (MA-Fungi 91901) (only slide), Lado 19556 (MA-Fungi 91902), Lado 19561a (MA-Fungi 91903), Lado 19581 (MA-Fungi 91904), Lado 19589 (MA-Fungi 91905). 
Other specimens examined: Hemitrichia intorta (Lister) Lister. BELGIUM. NAMUR: Malonne, sur écorce au sol, 22 Mar 1988, G. Thiry M687 (BR5020003245449). GERMANY. BADEN WÜRTTEMBERG NSG Reißinsel, 14 Mar 1976, Neubert 690 (M-0114003), Neubert 696 (M-0114009), Neubert 697 (M-0114010); 21 Mar 1976, Neubert 709 (M-0114022); HESSEN: Rhön, Ks. Fulda, Ehrenberg (Rhön), NSG “Schwarzwald," 700 m, MTB/Q 5525/2, an sbgeblätterter Borke unter abgestorbenem Stamm, ex Ulmus glabra, 1 Nov 2004, L. Krieglsteiner (KR-0022295); SAXONY: Görlitz-Landskrone, Gottschalk 912 (M-0118836). UNITED KINGDOM. HERTFORDSHIRE: Hitchin, $51.947^{\circ} \mathrm{N}, 0.283^{\circ} \mathrm{W}$, on decayed elm log, 4 Mar 1889, G. Lister (BM 299, BM001089127, lectotype of Hemiarcyria intorta Lister; see Lado and Wrigley de Basanta 2018). USA. IOWA: det. A. Lister (BPI 838683).

Comments: Hemitichia crassifila was found at nine localities in two separate years during late austral summer but at high elevations. Although no snow was recorded in the vicinity, the substrates had signs of a previous snow cover; therefore, we consider Hemitrichia crassifila a nivicolous species. Morphologically, the new species is similar to Hemitrichia intorta (Lister) Lister, which also has yellow to brownish-yellow stalked sporocarps (FIG. $7 \mathrm{~F})$. However, $H$. intorta has slightly darker and much smaller sporocarps, 0.30-0.70 mm diam (Lister 1891; Martin and Alexopoulos 1969; Neubert et al. 1993; Poulain et al. 2011) vs. (0.35-)0.55-1.10(-1.80) $\mathrm{mm}$ diam for $H$. crassifila, and smaller spores, $8-10 \mu \mathrm{m}$ diam (measured from the lectotype and other specimens studied: $8-10.5 \mu \mathrm{m}$ in total range, $9.0 \pm 0.6 \mu \mathrm{m}$ on average \pm $\mathrm{SD})$ vs. (12-)13-17(-21) $\mu \mathrm{m}$ in total range, $14.8 \pm 1.4 \mu \mathrm{m}$ on average $\pm \mathrm{SD}$ for $H$. crassifila. The most distinctive morphological characters between the two species are spore and capillitium dimensions and ornamentation. The spores of $H$. intorta are covered with low, thick, dispersed warts, and those of $H$. crassifila are more densely ornamented, with bacula fusing into short and irregular subreticulum (FIGS. 7C, H, 8D, H). The capillitium in $H$. intorta is formed by very long, sparingly branched threads, 3.5-4 $\mu \mathrm{m}$ thick, forming loops twisted upon themselves, and this character can be easily observed already under stereoscopic microscope (FIG. 8E). Additionally, spiral bands are regular, well marked, and connected by longitudinal stretch marks (Lister 1891) when observed under LM (FIG. $8 \mathrm{~F}-\mathrm{G}$ ), which is visible under SEM as a distinct reticulate or subreticulate pattern connecting spirals (FIG. 7I-J). The capillitium of $H$. crassifila is twice thicker, measuring 6-9 $\mu \mathrm{m}$ diam, not distinctly looped and forming a net (FIGS. 7A, 8A), with many distinctly spiny free ends (FIGS. 7E, 8B), covered by dense, irregular, branching and vanishing spirals without longitudinal stretch marks between them under LM and SEM (FIGS. 7E, 8C). Hemitichia intorta differs from the new species also by ecology, as it is not a nivicolous myxomycete. Hemitrichia crassifila has an undoubtedly distinct phylogenetic position in Trichiales (FIG. 2), interestingly, far from the most morphologically similar $H$. intorta. The new species clusters close to Trichia varia, the type species of the genus Trichia, and Perichaena corticalis (Batsch) Rostaf., the type species of Perichaena.

In the genus Hemitrichia, two nivicolous species, albeit morphologically distinct, have been recognized: $H$. montana and H. montanoides. Both clearly differ from $H$. crassifila by absent or rudimentary developed stalk, smaller spores, 10-13 $\mu \mathrm{m}$ diam (Poulain et al. 2011), smooth spiral bands, and by direction of spiral bands on elaters that in $H$. montana are left-handed, in $H$. montanoides are right-handed, and in $H$. crassifila are both left- and right-handed (FIGS. 7D, E, 8B, C). Unfortunately, we failed to obtain sequences for these two nivicolous species; thus, the phylogenetic relationship between nivicolous Hemitrichia species cannot be resolved.

Perichaena megaspora A. Ronikier, Lado \& D. Wrigley, Mycologia 105:939. 2013.

Description: See Ronikier et al. (2013).

Ecology and distribution: Nivicolous, known only from the Andes (Argentina; Ronikier et al. 2013). The Chilean record (also from a nivicolous locality) is the first for the country.

Specimens examined: ARGENTINA. ARG-08-11, on branches of Andean shrub (Asteraceae), Lado 19254 (MA-Fungi 91916), Lado 19255b (MA-Fungi 91917), Lado 19263 (MA-Fungi 91918), Lado 19264 (MAFungi 91919, duplicate in KRAM M-1765). CHILE. REGIÓN METROPOLITANA DE SANTIAGO: Santiago de Chile, Lo Barnechea, El Colorado (CHI$06-08), 33^{\circ} 20^{\prime} 39^{\prime \prime} \mathrm{S}, 70^{\circ} 17^{\prime} 25^{\prime \prime} \mathrm{W}, 2769 \mathrm{~m}$, on stem of Andean shrub (Asteraceae), 21 Mar 2006, A. EstradaTorres, C. Lado \& D. Wrigley de Basanta, Lado 17603 (MA-Fungi 80864).

Comments: The specimens reported here are from new localities, and their characters agree with the original description. Our phylogenetic results (FIG. 2) confirm the separate position of the species described originally based on morphology (Ronikier et al. 2013).

Perichaena patagonica A. Ronikier \& Lado, sp. nov. FIGS. 9A-D, 10A-D

MycoBank MB834667

Etymology: patagonica (Latin), from Patagonia, in reference to the region of the species' occurrence. 

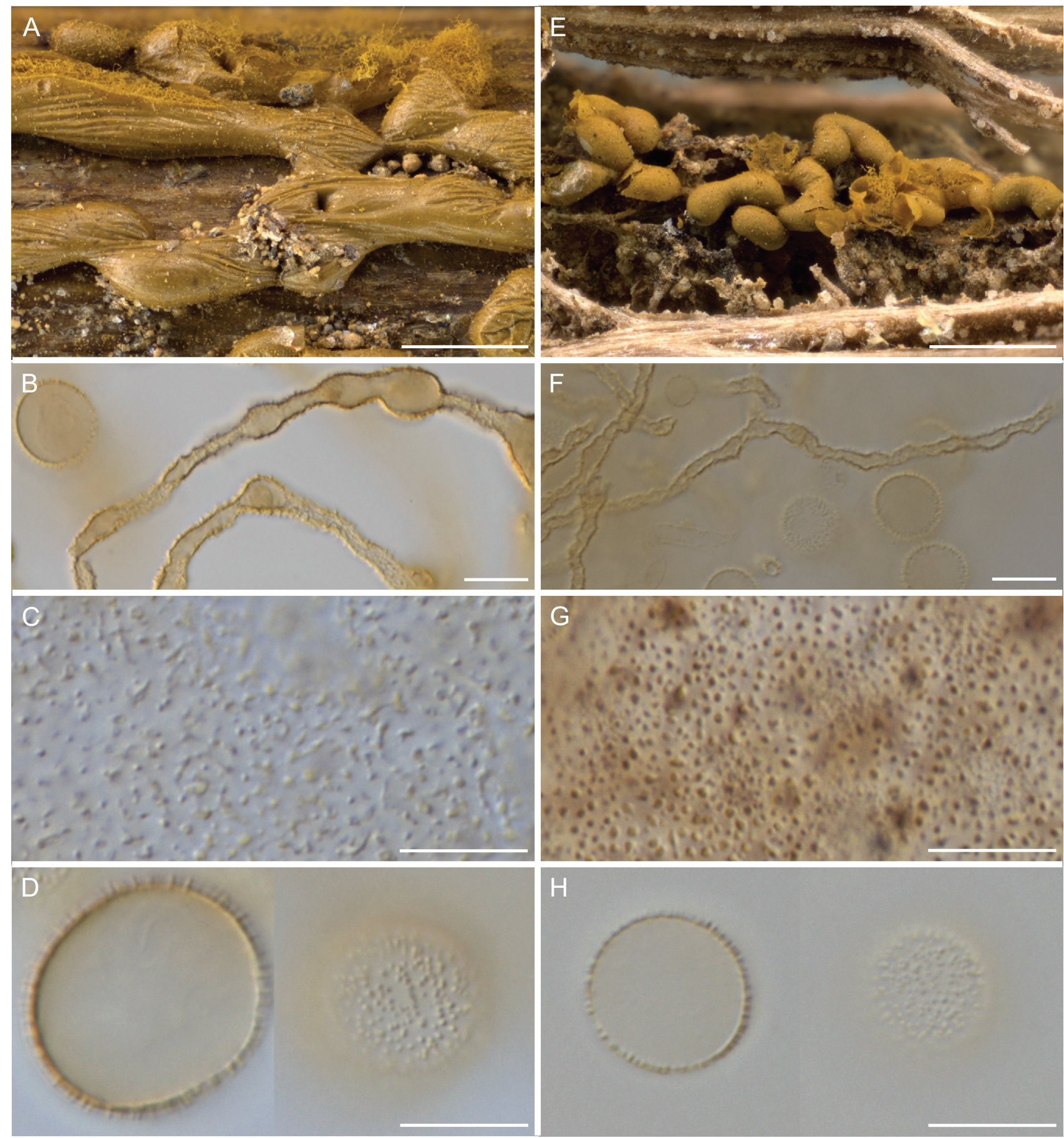

Figure 9. Comparison of Perichaena patagonica with P. vermicularis. A-D. P. patagonica. A. Plasmodiocarp of $P$. patagonica (Lado 20691, holotype). B. Capillitium (LM) (Lado 20815). C. Peridium inner surface (LM) (Lado 20718). D. Spores (LM) (Lado 20719). E-H. Perichaena vermicularis. E. Plasmodiocarp of $P$. vermicularis (MA-Fungi 29450). F. Capillitium (LM) (BPI 830738). G. Peridium inner surface (LM) (BPI 830686). H. Spores (LM) (BPI 830738). Bars: A, $E=1 \mathrm{~mm} ; \mathrm{B}-\mathrm{D}, \mathrm{F}-\mathrm{H}=10 \mu \mathrm{m}$.

Typification: ARGENTINA. RIO NEGRO: Bariloche, San Carlos de Bariloche, Cerro Catedral, $41^{\circ} 09^{\prime} 49^{\prime \prime} \mathrm{S}, 71^{\circ}$ 27'34"W, 1364 m (ARG-09-62), on branches of Lupinus sp. near melting snow, 21 Nov 2009, A. Estrada-Torres, E. García, C. Lado, A. Ronikier \& D. Wrigley de Basanta, Lado 20691 (holotype MA-Fungi 91906, isotype KRAM M-1522). GenBank: 18S = MT154034; EF-1 $\alpha=$ MT162173.
Diagnosis: Sporophores ochraceous-yellow, plasmodiocarps large, spores spiny, (13-)14-19(-20) $\mu \mathrm{m}$, differing from the most similar $P$. vermicularis by the twice larger dimensions of sporophores and spore size and ornamentation. Nivicolous in mountains of South America.

Description: Sporophores plasmodiocarpic, scattered or in groups, sessile, sometimes accompanied with single 
sporocarps, pale ochraceous-yellow. Plasmodiocarps elongated, branched or reticulate, (0.95-)2.50-9.00(15.00) $\mathrm{mm}$ long, $0.65-1.00(-1.15) \mathrm{mm}$ wide, and $0.35-0.75 \mathrm{~mm}$ high $(\mathrm{n}=31)$ (FIG. 9A). Hypothallus inconspicous to thick, concolorous with the sporophores, shinning. Stalk absent. Peridium single but thick, ochraceous-yellow to pale ochraceous-yellow under LM, covered with slightly darker granular matter, inner surface distinctly reticulated and densely warted (FIGS. 9C, 10A), dehiscence irregular. Capillitium pale ochraceous-yellow in mass, pale orange-yellow under LM, abundant, dense, delicate, buildup of long, irregular tubules with many branches, forming a loose net-like structure, with few free ends and many swellings, capillitial tubules, 3-6(-7) $\mu \mathrm{m}$ wide $(\mathrm{n}=44)$, variable in ornamentation pattern, densely ornamented with more or less prominent papillae or spinules connected with lines (FIGS. 9B, 10B). Spores pale ochraceous in mass, pale ochraceous-yellow under LM, slightly paler at one side, globose, (13-)14-19(-20) $\mu \mathrm{m}$ in total range, $15.9 \pm$ $1.5 \mu \mathrm{m}$ on average $\pm \mathrm{SD}(\mathrm{S}=300)$, covered by spines of about $1 \mu \mathrm{m}$ long, baculate to slightly pilate under SEM, bacula or pila higher than wide (FIGS. 9D, 10C-D). Plasmodium unknown.

Ecology and distribution: Occurring after snow melt at elevations below $1500 \mathrm{~m}$, austral Andes, Argentina, austral spring.

Additional specimens examined: ARGENTINA. ARG09-62, on branches of Lupinus sp., near melting snow, Lado 20676 (MA-Fungi 91907), Lado 20686 (MA-Fungi 91908), Lado 20718 (MA-Fungi 91909), Lado 20729 (MAFungi 91910), Lado 20731a (MA-Fungi 91911), Lado 20733 (MA-Fungi 91912); on branches of leaving bush (Asteraceae), near melting snow, Lado 20719 (MA-Fungi 91913) (duplicate in KRAM M-1756); ARG-09-63, on grasses, near melting snow, Lado 20815 (MA-Fungi 91914); on grasses and branches of Nothofagus pumilio, near melting snow, Lado 20835c (MA-Fungi 91915).

Other specimens examined: Perichaena vermicularis (Schwein.) Rostaf. BELGIUM. ANTWERP: Wilrijk, Fort 7, on Urtica dioica, 8 Feb 1994, H. De Meulder 9566 (BR5020025765604). NETHERLANDS. Doorwerth Zoo, 30 Mar 1958, E. Nannenga-Bremekamp 2533 (BPI 830738). SWITZERLAND. GRAUBÜNDEN: Inner decaying bark, last week of Aug to last week of Sep 1971, M.L. Farr 4228 (BPI 830727). SPAIN. ALMERÍA: Las Negras, 30SWF8982, $30 \mathrm{~m}$, cladode of Opuntia ficus-indica, 29 Dec 1983, C. Lado 1592 (MAFungi 29450); PONTEVEDRA: Bueu, Beluso, 29TNG1586, $50 \mathrm{~m}$, on leaves of Laurus nobilis and Rubus sp., 27 Dec 1989, J. Portela, Lado 4036 (MAFungi 85379). USA. IOWA: Iowa city, Feb 1950, G.W. Martin 202 (BPI 830686); COLORADO: Montrose
County, Juniperus osteosperma, 18 Apr-28 May 1980, J. R. McBride 10,682 (BPI 830666); Montrose County, juniper bark, 18 Apr-19 May 1980, J.R. McBride 10,369 (BPI 830669); UTAH: Zion National Park, substrate: wild grape bark, 30 Mar-10 Apr 1984, J.R. McBride 14,910 (BPI 830670).

Comments: Perichaena patagonica was found on dead and living branches of plants, at two different localities in the Andes during the period of snow thawing in austral spring. It has not been recorded later during the season; thus, we consider P. patagonica undoubtedly a nivicolous myxomycete. Perichaena patagonica macroscopically resembles $P$. vermicularis (FIG. 9E), a common and worldwide distributed species, since they both form branched, pale yellow to ochraceous plasmodiocarps, but it is much larger (FIG. 9A). Perichaena vermicularis has plasmodiocarps up to $0.5 \mathrm{~mm}$ wide (see Martin and Alexopoulos 1969; Neubert et al. 1993; Poulain et al. 2011), whereas $P$. patagonica plasmodiocarps are from $0.65 \mathrm{~mm}$ up to $1.15 \mathrm{~mm}$ wide. Microscopically, the two species can be differentiated by the inner peridium surface ornamentation (FIGS. 9C, G, 10A, E) and spore size and ornamentation (FIGS. 9D, H, 10C-D, G-H). The spores of $P$. patagonica are larger, (13-)14-19(-20) $\mu \mathrm{m}$ in total range, $15.9 \pm 1.5 \mu \mathrm{m}$ on average \pm SD vs. $11-14 \mu \mathrm{m}$ diam in $P$. vermicularis, and covered with more prominent spines, about $1 \mu \mathrm{m}$ high (FIGS. 9D, 10C-D) vs. less than $0.5 \mu \mathrm{m}$ in $P$. vermicularis (FIGS. 9H, 10G-H). The capillitium is similar in both species, but twice wider, 3-6(-7) $\mu \mathrm{m}$ in $P$. patagonica vs. $2-3.5 \mu \mathrm{m}$ in P. vermicularis (FIG. 9B, F). Additionally, the capillitium ornamentation is very variable in $P$. patagonica, either reticulate or ornamented with reticulum densely covered with cylindrical papillae under SEM (FIGS. 9B, 10B). Large variation in decoration of capillitium tubules has already been observed in two other Perichaena species, P. calongei (Lado et al. 2009) and P. megaspora (Ronikier et al. 2013); thus, we consider this character of lesser taxonomic importance.

Perichaena patagonica is the second nivicolous species described from South America. The first one, P. megaspora, has spores slightly larger than those of P. patagonica, measuring (15-)15.5-22(-25) $\mu \mathrm{m}$ in total range, $18.5 \pm 1.5$ on average $\pm \mathrm{SD}(\mathrm{S}=1050)$, and variably ornamented capillitium tubules (Ronikier et al. 2013). It clearly differs by shorter plasmodiocarpic or sporocarpic and darker fructifications and spore ornamentation composed of loosely arranged large warts that are wider than high.

Our phylogenetic results confirm the separate position of $P$. patagonica that clusters together with $P$. vermicularis and $P$. megaspora but outside the type 

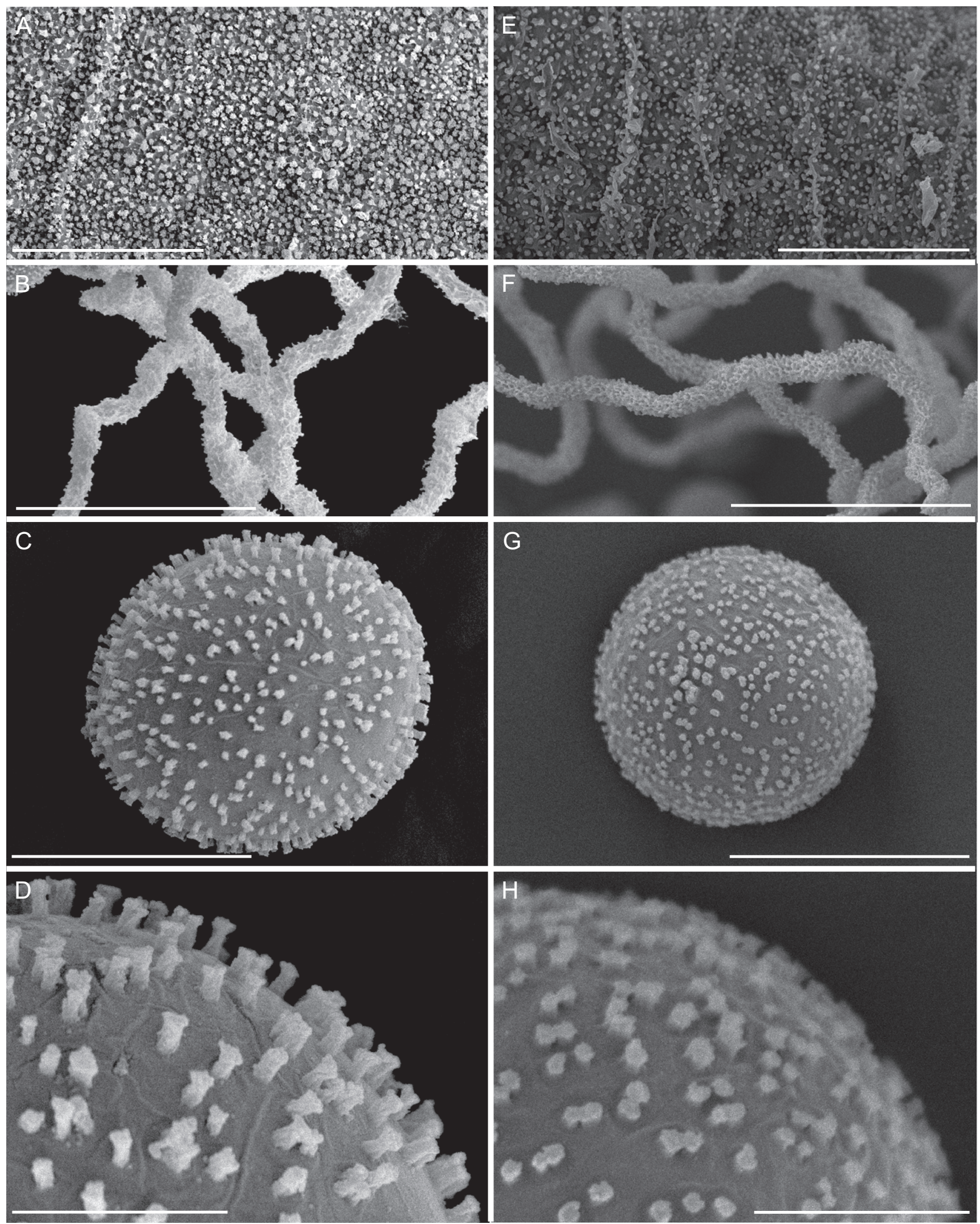

Figure 10. Comparison of Perichaena patagonica with P. vermicularis. A-D. P. patagonica (Lado 20691, holotype). A. Peridium inner surface (SEM). B. Capillitium (SEM). C. Spore (SEM). D. Details of spore ornamentation (SEM). E-H. P. vermicularis (MA-Fungi 85379). E. Peridium inner surface (SEM). F. Capillitium (SEM). G. Spore (SEM). H. Details of spore ornamentation (SEM). Bars: $A, E=20 \mu m ; B, F=30$ $\mu \mathrm{m} ; \mathrm{C}, \mathrm{G}=10 \mu \mathrm{m} ; \mathrm{D}, \mathrm{H}=3 \mu \mathrm{m}$. 
species of the genus, $P$. corticalis (FIG. 2).

\section{Perichaena sp.}

Specimen examined: ARGENTINA. ARG-09-16, on branches of Adesmia sp., Lado 20330 (MA-Fungi 91920).

Comments: The specimen represents a deviating morphotype differing from $P$. vermicularis by darker brown sporophores and larger spores, (14-)14.5-16(-17) $\mu \mathrm{m}$ in total range, $15.3 \pm 0.7 \mu \mathrm{m}$ on average $\pm \mathrm{SD}(\mathrm{S}=30)$. It is quite similar to the collections reported and illustrated by Lado et al. (2014: fig. 3F) as Perichaena vermicularis from non-nivicolous localities in Argentina. Perichaena vermicularis is a common and worldwide distributed species, occurring in various habitats and substrates, and it is also common and morphologically variable in the SH (Lado et al. 2007, 2011, 2013, 2014, 2016; Lado and Wrigley de Basanta 2008). Before the taxonomic position of our single collection is resolved, detailed morphological and phylogenetic revision of South American specimens of $P$. vermicularis should be undertaken.

Trichia affinis de Bary, in Fuckel, Jahrb Nassauischen Vereins Naturk 23-24:336. 1870.

Description: A few to several, grouped, sessile, bright yellow to ochraceous-yellow sporocarps, rarely short plasmodiocarps, filled with yellow to yellow-orange capillitium and spores. Elaters of capillitium shortended, (5.5-)6-7(-7.5) $\mu \mathrm{m}$ wide in total range, $6.4 \pm$ $0.5 \mu \mathrm{m}$ on average \pm SD $(\mathrm{n}=110)$, with spirals smooth or covered with tiny, scattered spines. Spores pale yellow under LM, (12-)13-15 $\mu \mathrm{m}$ in total range, $13.6 \pm 0.7 \mu \mathrm{m}$ on average \pm SD $(S=110)$, covered by incomplete, largemeshed and thick-meshed reticulum with additional, broken (wart-like) parts of ridges. For description of NH material, see Neubert et al. (1993), Lado and Pando (1997), and Poulain et al. (2011).

Ecology and distribution: Not nivicolous. In the SH reported from Australia, New Zealand (e.g., Lister and Lister 1905; Cheesman and Lister 1915; Mitchell 1992), Argentina, Chile, and Ecuador (Lado et al. 2007, 2013, 2014; Lado and Wrigley de Basanta 2008; Wrigley de Basanta et al. 2010) but from non-nivicolous localities. All the collections studied here have been collected near melting snow patches; thus, the species seems to be facultatively nivicolous.

Specimens examined: ARGENTINA. ARG-09-63, on branches of Nothofagus pumilio, Lado 20760b (MAFungi 91921); on bark of branch of Nothofagus pumilio, Lado 20772 (MA-Fungi 91922), Lado 20819 (MA-Fungi 91923, duplicate in KRAM M-1520), Lado 20824 (MAFungi 91924), Lado 20909a (MA-Fungi 91925); on branches of Nothofagus pumilio, Lado 20781 (MAFungi 91926), Lado 20839 (MA-Fungi 91927), Lado
20851 (MA-Fungi 91928); on wood of Nothofagus pumilio, Lado 20793 (MA-Fungi 91929), Lado 20810 (MAFungi 91930), Lado 20847 (MA-Fungi 91931).

Trichia alpina (R.E. Fr.) Meyl., Bull Soc Vaud Sci Nat 53:460. 1921.

$\equiv$ Trichia contorta var. alpina R.E. Fr., Ark Bot 6:5. 1906.

Description: Sporophores scattered or in groups, often in rows, in the form of sporocarps or short to elongated plasmodiocarps, sessile, broadly attached to the substrate, $0.65-15.50 \mathrm{~mm}$ long, $0.55-0.85 \mathrm{~mm}$ wide, and $0.45-0.70 \mathrm{~mm}$ high $(\mathrm{n}=18)$, dark red-brown, blackish-brown to almost black, dull. Hypothallus inconspicuous. Peridium dark yellow-brown under LM, double, the outer layer thick, brittle, composed of granulose matter, the inner layer thin, translucent, dehiscence irregular. Capillitium bright yellow in mass, concolorous with spores, composed of thick elaters, $6-8.5 \mu \mathrm{m}$ wide in total range, $7.2 \pm 0.8 \mu \mathrm{m}$ on average $\pm \mathrm{SD}$, with (3-)4-5 spiral bands, covered with short, scattered spines, with many free ends, short, blunt, usually slightly swollen. Spores free, bright yellow in mass, pale yellow to almost hyaline under LM, globose, (14.0-)15.0-21.0(-24.0) $\mu \mathrm{m}$ in total range, $16.8 \pm 1.6 \mu \mathrm{m}$ on average $\pm \mathrm{SD}(\mathrm{S}=113)$, minutely warted, thick- or thin-walled.

Ecology and distribution: Nivicolous. In the $\mathrm{SH}$ reported from Australia, the subantarctic Macquarie Island (Stephenson et al. 2007), and from Chile (Lado et al. 2013). This is a new record for Argentina.

Specimens examined: ARGENTINA. ARG-07-37, on branch of Andean shrub (Asteraceae), Lado 18615 (MAFungi 91932), Lado 18656a (MA-Fungi 91933, duplicate in KRAM M-1498); ARG-09-63, on branch of Nothofagus pumilio, Lado 20904 (MA-Fungi 91934); on bark of branch of Nothofagus pumilio, Lado $20929 \mathrm{~b}$ (MA-Fungi 91935).

Other specimens examined: FRANCE. SAVOIE: Massif de la Vanoise, Méribel-Altiport, montane meadow, at the melting snow patch, $1855 \mathrm{~m}$, on plant remnants, 27 Apr 2008, A. Ronikier \& M. Ronikier, Ron 496 (KRAM M-1349). POLAND. The Carpathians, ridge of Turbacz Mountain, surroundings of the glade Turbacz, $\mathrm{N}$ slopes, meadow, $20^{\circ} 06^{\prime} 36^{\prime \prime} \mathrm{E}, 49^{\circ} 32^{\prime} 50^{\prime \prime} \mathrm{N}, 1230 \mathrm{~m}$, on stems of Vaccinium myrtillus, 13 May 2006, A. Ronikier \& M. Ronikier (KRAM M-1155). SPAIN. ÁVILA: Zapardiel de la Ribera, southwestern upper part of the Circo de Gredos, $40^{\circ} 14^{\prime} 45^{\prime \prime} \mathrm{N}, 05^{\circ} 17^{\prime} 22^{\prime \prime} \mathrm{W}$, 2200-2250 m, small patches of alpine meadows among granitic rocks, on inflorescence of Eryngium bourgatii, 1 Jun 2003, A. Ronikier \& M. Ronikier (KRAM M-1047); LÉRIDA: Alt Aneu, Valencia 
d'Aneu, Ruda valley, circo de Saboredo, 42 $37^{\prime} 50^{\prime \prime} \mathrm{N}$, $0^{\circ} 57^{\prime} 44^{\prime \prime} \mathrm{E}, 2000 \mathrm{~m}$, on branch of Salix sp., 5 Jun 1996, Lado 8151 (MA-Fungi 73210).

Comments: The Andean specimens are typical in macro- and microcharacters and agree with the description of NH specimens provided by different authors (e.g., Neubert et al. 1993; Lado and Pando 1997; Kuhnt 2006; Poulain et al. 2011).

Trichia contorta var. karstenii (Rostaf.) Ing, Trans $\mathrm{Br}$ Mycol Soc 48:647. 1965. FIG. 11

$\equiv$ Hemiarcyria karstenii Rostaf., Sluzowce Monogr Suppl:41. 1876.

Description: Slightly elongated sporocarps or plasmodiocarps, $0.75-1.55(-3.35) \times 0.50-0.90 \mathrm{~mm}$, height 0.50-0.85 mm $(\mathrm{n}=6)$, unevenly colored, darker at base, olivaceous-brown, paler toward the upper part, honey-yellow (FIG. 11A). Capillitium honey-yellow in mass, trichioid to semitrichioid (see Kuhnt 2006), composed of very long elaters with numerous branches and swellings, 3.5-4 $\mu \mathrm{m}$ thick, with 12-22 $\mu \mathrm{m}$ long endings and decorated with delicate spirals (FIG. 11B, E). Spores yellow in mass, pale yellow under LM, 11.5-14(-14.5) $\mu \mathrm{m}$ in total range, $12.6 \pm 0.6 \mu \mathrm{m}$ on average \pm SD $(S=60)$, spiny under LM, covered by pilae under SEM (FIG. 11C, F).

Ecology and distribution: This is the first record of the variety from South America to date. Neotropical records provided by Lado and Wrigley de Basanta (2008) are from Mexico.

Specimens examined: ARGENTINA. ARG-09-16, on leaves of Adesmia sp., Lado 20326 (MA-Fungi 91956);
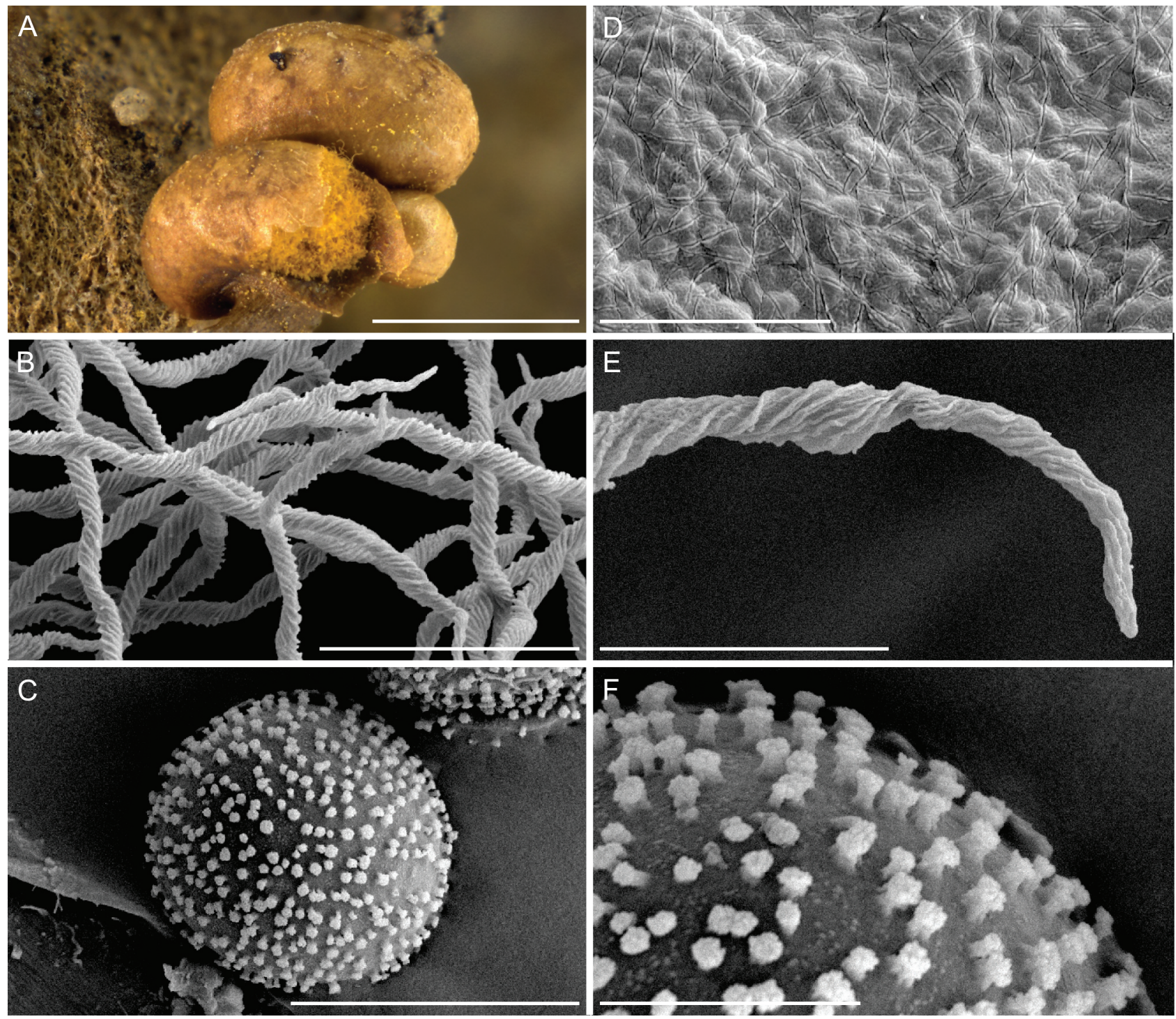

Figure 11. Trichia contorta var. karstenii (Lado 20331). A. Group of sporocarps. B. Capillitium (SEM). C. Spore (SEM). D. Peridium inner surface (SEM). E. Capillitial end (SEM). F. Details of spore ornamentation (SEM). Bars: $A=1 \mathrm{~mm} ; B=30 \mu \mathrm{m} ; C, E=10 \mu \mathrm{m} ; \mathrm{D}=20 \mu \mathrm{m} ; \mathrm{F}=$ $3 \mu \mathrm{m}$. 
on branches of Adesmia sp., Lado 20331 (MA-Fungi 91957, duplicate in KRAM M-1759).

Comments: The two collections differ from austral specimens of Trichia nivicola by branching elaters that have longer endings (FIG. 11E) and are decorated by delicate spirals. Another distinctive feature is spore ornamentation, less dense but composed of more pronounced spines, easily visible under LM (oil immersion), similar to those illustrated by Neubert et al. (1993:297) for NH specimens, and slightly pilate under SEM (FIG. 11F; see FIG. 12F for comparison). For description of $\mathrm{NH}$ material, see Neubert et al. (1993), Lado and Pando (1997), and Poulain et al. (2011).

Trichia crateriformis G.W. Martin, Mycologia 55:131. 1963.

Description: Only one, slightly damaged specimen was collected at a nivicolous locality. Sporocarps stalked, sporotheca orange-yellow to brownish-yellow. Stalks filled with cyst-like elements. Spores globose, $12-14 \mu \mathrm{m}$ in total range, $13.0 \pm 0.6$ on average $\pm \mathrm{SD}(\mathrm{S}=30)$, covered by high, short ridges composed of a few fused warts.

Ecology and distribution: Described originally from New Zealand (Martin 1962, 1963) as T. craterioides G. W. Martin, not T. craterioides Corda, further reported from Argentina (Lado et al. 2014) and Madagascar (Wrigley de Basanta et al. 2013).

Specimen examined: ARGENTINA. ARG-09-63, on wood of Nothofagus pumilio, Lado 20813 (MA-Fungi 91958).

Comments: We identified our collection as $T$. decipiens var. olivacea (Meyl.) Meyl., the taxon that Moreno and Castillo (2013) considered a synonym of T. crateriformis. The spores of the Andean specimen are slightly larger, 12-14 $\mu \mathrm{m}$ diam, than those of the type material of T. crateriformis, 11-12.5 $\mu \mathrm{m}$ diam, than those of the type material of T. fallax var. olivacea Meyl., 11-12 $\mu \mathrm{m}$, studied by Moreno and Castillo (2013), and than those of other NH collections, 10-13 $\mu$ m diam (see Neubert et al. 1993; Poulain et al. 2011, as T. decipiens var. olivacea; Martin and Alexopoulos 1969). This is the first record of the species at a nivicolous locality, but since it was scarce and damaged, it cannot be excluded that the collection represents residue of the autumnal fructification. In the $\mathrm{NH}$, the species is usually noted under the name Trichia decipiens var. olivacea (e.g., Neubert et al. 1993; Poulain et al. 2011).

Trichia lutescens (Lister) Lister, J Bot 35:216. 1897.

$\equiv$ Trichia contorta var. lutescens Lister, Monogr Mycetozoa, ed. 1:169. 1894.
Description: Only one collection with a small group of sporophores has been found. Sporocarps 0.70-1.25 mm in diam $(\mathrm{n}=5)$, bright yellow, dull when filled with spores, but yellow and shinning when the spores are dispersed. Peridium single, thin, transparent, yellow, and smooth under LM. Capillitium yellow, citrine-yellow under LM, formed by elaters 5-7 $\mu \mathrm{m}$ wide, covered with four smooth spiral bands; ends pointed, 13-18 $\mu \mathrm{m}$ long. Spores yellow in mass, pale yellow under LM, globose, 11-13 $(-14.5) \mu \mathrm{m}$ in total range, $12.4 \pm 0.7 \mu \mathrm{m}$ on average \pm SD $(S=30)$, covered with irregularly distributed spines up to $1 \mu \mathrm{m}$ long, some neighboring spines seem to fuse under LM. For description of $\mathrm{NH}$ material; see Neubert et al. (1993), Lado and Pando (1997), and Poulain et al. (2011).

Ecology and distribution: Not strictly nivicolous, but sometimes noted near melting snow (e.g., Lado and Ronikier 2008). In the SH reported from New Zealand (Rawson 1937; Mitchell 1992; Stephenson 2003), Argentina, Brazil, and Chile (Lado and Wrigley de Basanta 2008; Wrigley de Basanta et al. 2010; Lado et al. 2013, 2014).

Specimen examined: ARGENTINA. ARG-09-62, on wood of Nothofagus sp., Lado 20648 (MA-Fungi 91959).

Additional specimen examined: SPAIN. HUESCA: Bielsa, trail to Urdiceto Lake, $42^{\circ} 45^{\prime} 20^{\prime \prime} \mathrm{N}, 0^{\circ} 27^{\prime} 35^{\prime \prime} \mathrm{W}$, 1800 m, on trunk of Corylus avellana, 19 Jun 1991, Lado 5275 (MA-Fungi 73214).

Trichia nivicola Kuhnt, Ber Bayer Bot Ges 89:213. 2019.

FIG. 12

Description: Sporophores in small to large colonies of sessile sporocarps or short plasmodiocarps, 0.60-1.10(1.65) $\mathrm{mm}$ long, (0.40-)0.46-0.90(-1.00) $\mathrm{mm}$ wide, $0.40-0.95 \mathrm{~mm}$ high $(\mathrm{n}=61)$, uniformly colored, chestnutbrown, rusty-brown to yellow-brown or bicolored, shining, yellow-brown to rusty-brown with well marked matt chestnut-brown ruptured thicker areas (FIG. 12A). Peridium double, outer layer continuous or fragmented and then unveiling inner layer, inner side of the inner layer decorated with wrinkled-reticulate-porous pattern (FIG. 12D), dehiscence irregular. Capillitium trichioid, rusty-yellow in mass, paler than peridium, the elaters not very long, shortended, ends 6-15 $\mu \mathrm{m}$ long $(\mathrm{n}=33)$, decorated with wide and tightly attached spirals (FIG. 12B, E). Spores honeyyellow to golden-yellow in mass, slightly paler than the capillitium, bright yellow under LM, slightly darker and thick-walled at one side, globose, $10.0-12(-13.5) \mu \mathrm{m}$ in total range, $11.2 \pm 0.7 \mu \mathrm{m}$ on average $\pm \mathrm{SD}(\mathrm{S}=570)$, covered with short and irregularly arranged warts, short baculae with rough surface under SEM (FIG. 12C, F). 

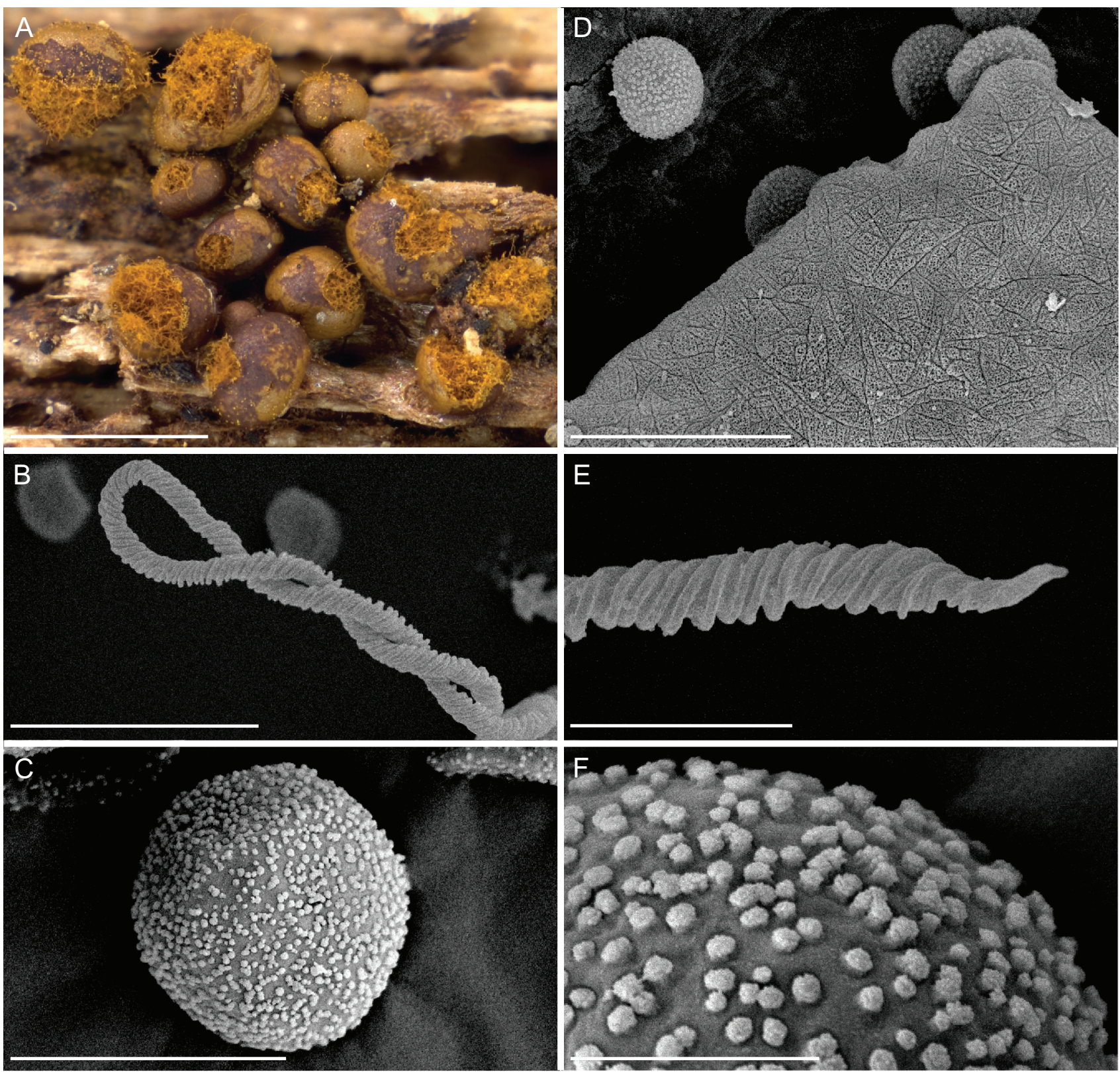

Figure 12. Trichia nivicola. A. Group of sporocarps (Lado 20653). B. Capillitium (SEM) (Lado 20895). C. Spore (SEM) (Lado 20650). D. Peridium inner surface (SEM) (Lado 20895). E. Capillitial end (SEM) (Lado 20895). F. Details of spore ornamentation (SEM) (Lado 20652). Bars: $A=1 \mathrm{~mm} ; B=30 \mu \mathrm{m} ; C, E=10 \mu \mathrm{m} ; \mathrm{D}=20 \mu \mathrm{m} ; \mathrm{F}=3 \mu \mathrm{m}$.

Ecology and distribution: Described very recently as a nivicolous species occurring in Europe (the Alps and the Scandinavia) and in the North America (Alaska). Our records are the first from the SH, but it cannot be excluded that Trichia contorta (Ditmar) Rostaf. reported from nivicolous locality in New Zealand (Stephenson and Johnston 2003) represents T. nivicola.

Specimens examined: ARGENTINA. ARG-09-16, on branch of living Nothofagus sp., Lado 20342 (MA-Fungi 91936); ARG-09-62, on wood of Nothofagus sp., Lado 20649 (MA-Fungi 91942); on wood and bark of Nothofagus sp., Lado 20650 (MA-Fungi 91937, duplicate in KRAM M-1757), Lado 20651 (MA-Fungi 91938), Lado 20652 (MA-Fungi 91939, duplicate in KRAM M-1758), Lado 20653 (MA-Fungi 91943, duplicate in KRAM M-1760), Lado 20654 (MA-Fungi 91944, duplicate in KRAM M-1761), Lado 20655 (MA-Fungi 91945), Lado 20656 (MA-Fungi 91946), Lado 20657 (MA-Fungi 91947) (duplicate in KRAM M-1762); on bark of Nothofagus sp., Lado 20664 (MA-Fungi 91948), Lado 20666 (MA-Fungi 91949); on branch of Nothofagus sp., Lado 20670 (MA-Fungi 91950), Lado 20697 (MA-Fungi 91940), Lado 20698 (MA-Fungi 91941), Lado 20751 (MA-Fungi 91955); on branch of Nothofagus pumilio, 
Lado 20708 (MA-Fungi 91951); ARG-09-63, on wood of Nothofagus pumilio, Lado 20843 (MA-Fungi 91952); on bark of branch of Nothofagus pumilio, Lado 20895 (MAFungi 91953, duplicate in KRAM M-1763), Lado 20707 (MA-Fungi 91954, duplicate in KRAM M-1774).

Other specimens examined: Trichia contorta. LUXEMBURG: Pine Hollm, on aspen, 3 Oct 1931, G.W. Martin (BPI 835520). SWITZERLAND. GRAUBÜNDEN: Sertig Tal, inside decaying bark of Alnus viridis, 2 Sep 1971, B.C. Lodha (BPI 835417). USA. MASSACHUSETTS: N. Weymouth, on dead trunk, 28 Nov 1888, J.E. Humphrey (BPI 835494).

Comments: The Andean specimens fits very well the description of T. nivicola (Kuhnt 2019), and they have all essential characters of that species: peridium inner side decorated with wrinkled-reticulate-porous ("fingerprint"like) pattern (FIG. 12D), large and bright germination area on spores, the rough (mulberry-like) warts covering spores under SEM (Fig. 12F), short-ended elaters (Fig. 12E), and nivicolous ecology. NH collections of T. nivicola usually occur on dead plant material, but not on bark or wood, whereas all Andean collections were found on bark or wood what is a substrate typical for T. contorta (Ditmar) Rostaf. (Martin and Alexopoulos 1969; Poulain et al. 2011). Trichia nivicola is very easily distinguished from two other nivicolous species of the genus, T. alpina and T. sordida Johannesen, based on numerous macro- and micromorphological characters (Kuhnt 2019), but the author does not present its clear separation from the non-nivicolous $T$. contorta. It seems that apart from ecology, the two species can be separated based on elater ends that in T. contorta are longer (15-20 $\mu \mathrm{m}$; see, e.g., Poulain et al. 2011). Since $T$. contorta is a very common, cosmopolitan species with many varieties and forms recognized on one hand and only two partial $18 \mathrm{~S}$ sequences available in the GenBank repository on the other, the comprehensive phylogenetic analysis of the species is needed. Several collections (Lado 18678, Lado 18769, Lado 18778, Lado 19586, Lado 18763, Lado 18795, Lado 18766, Lado 18791) with badly developed (Oligonema-like) capillitium may represent $T$. nivicola. They cannot be identified with certainty; thus, they were excluded from these studies. Similar type of capillitium was reported for T. nivicola in the original description (Kuhnt 2019).

Trichia sordida Johannesen, Mycotaxon 20:81. 1984. FIG. 13

Description: Sporophores sessile, 1.00-2.35(2.90) $\mathrm{mm}$ long, (0.75-)0.90-1.60(-2.05) mm wide, and $0.75-1.60 \mathrm{~mm}$ high $(\mathrm{n}=78)$, yellow, with very faint darker strips or points on the surface, sometimes difficult to notice, rarely very well visible (FIG. 13A). Peridium single, inner side covered with wrinkled- reticulate pattern and papillae (FIG. 13D). Capillitium dense, elastic, orange to copper-orange in mass, composed of very long elaters, $5-7(-8) \mu \mathrm{m}$ thick, with free, pointed ends 15-72 $\mu \mathrm{m}$ long $(\mathrm{n}=29)$ (FIG. 13E); elaters with few branches, not forming a net, usually with many short side branches about $30 \mu \mathrm{m}$ long, and quite many swellings (FIG. 13B). Spores yellow in mass, pale yellow under LM, (10-)10.5-13(-14) $\mu \mathrm{m}$ in total range, $11.8 \pm$ $0.6 \mu \mathrm{m}$ on average \pm SD $(S=480)$, densely and finely warted, pilate under SEM, with large capita that are sometimes connected to each other with a tendency to form a tegillum (FIG. 13C, F) (see Rammeloo 1974).

Ecology and distribution: Nivicolous. Known from Europe, Asia, and North America (Poulain et al. 2011), not previously reported from the $\mathrm{SH}$.

Specimens examined: ARGENTINA. ARG-09-62, on herbaceous litter, Lado 20694 (MA-Fungi 91960, duplicate in KRAM M-1510); on branch of Nothofagus pumilio, Lado 20703 (MA-Fungi 91961); ARG-09-63, on wood of Nothofagus pumilio, Lado 20737 (MA-Fungi 91962, duplicate in KRAM M-1519); on branch of Nothofagus pumilio, Lado 20750 (MA-Fungi 91963), Lado 20760a (MA-Fungi 91964, duplicate in KRAM M-1517), Lado 20774 (MA-Fungi 91965) (duplicate in KRAM M-1512), Lado 20829 (MA-Fungi 91966) (duplicate in KRAM M-1514), Lado 20832 (MA-Fungi 91967), Lado 20898 (MA-Fungi 91968, duplicate in KRAM M-1764); on leaves of Nothofagus pumilio, Lado 20784 (MA-Fungi 91969, duplicate in KRAM M-1516); on branch of leaving Nothofagus pumilio, Lado 20812 (MAFungi 91970); on grasses and herbaceous litter, Lado 20823 (MA-Fungi 91971, duplicate in KRAM M-1515); on herbaceous litter, Lado 20833 (MA-Fungi 91972); on leaves of Nothofagus pumilio, Lado 20834 (MA-Fungi 91973); on grasses, Lado 20856 (MA-Fungi 91974); on bark of branch of Nothofagus pumilio, Lado 20858 (MAFungi 91975, duplicate in KRAM M-1513); on grasses and litter, Lado 20860a (MA-Fungi 91976, duplicate in KRAM M-1511).

Other specimens examined: NORWAY. AKERSHUS: Bærum, near Furuholmen in Vestmarka, on dead grass near melting snow, 8 May 1975, K. Høiland (holotype O F-72785). FRANCE. SAVOIE: Doucy, $45.51429^{\circ} \mathrm{N}$, $6.46821^{\circ} \mathrm{E}, 1100-1200 \mathrm{~m}$, spruce-beech forest, fallen beech twig, 17 Apr 2018, A. Ronikier 720 (KRAM M-1772); La Bathie, $45.62998^{\circ} \mathrm{N}, 6.47543^{\circ} \mathrm{E}, 1350 \mathrm{~m}$, forest edge, 20 Apr 2018, A. Ronikier 814 (KRAM M-1773). Trichia sordida var. sordidoides Illana \& G. Moreno. SPAIN. SEGOVIA: San Ildefonso, Puerto de Navacerrada, $1950 \mathrm{~m}$, en ramas de Pinus sylvestris, 11 May 2003, A. Sánchez (AH 32455); MADRID: Rascafría, Puerto de Cotos, Valdesqui, 1850 m, en corteza de Pinus sylvestris, 23 Apr 1999, A. Sánchez (AH 25973). 

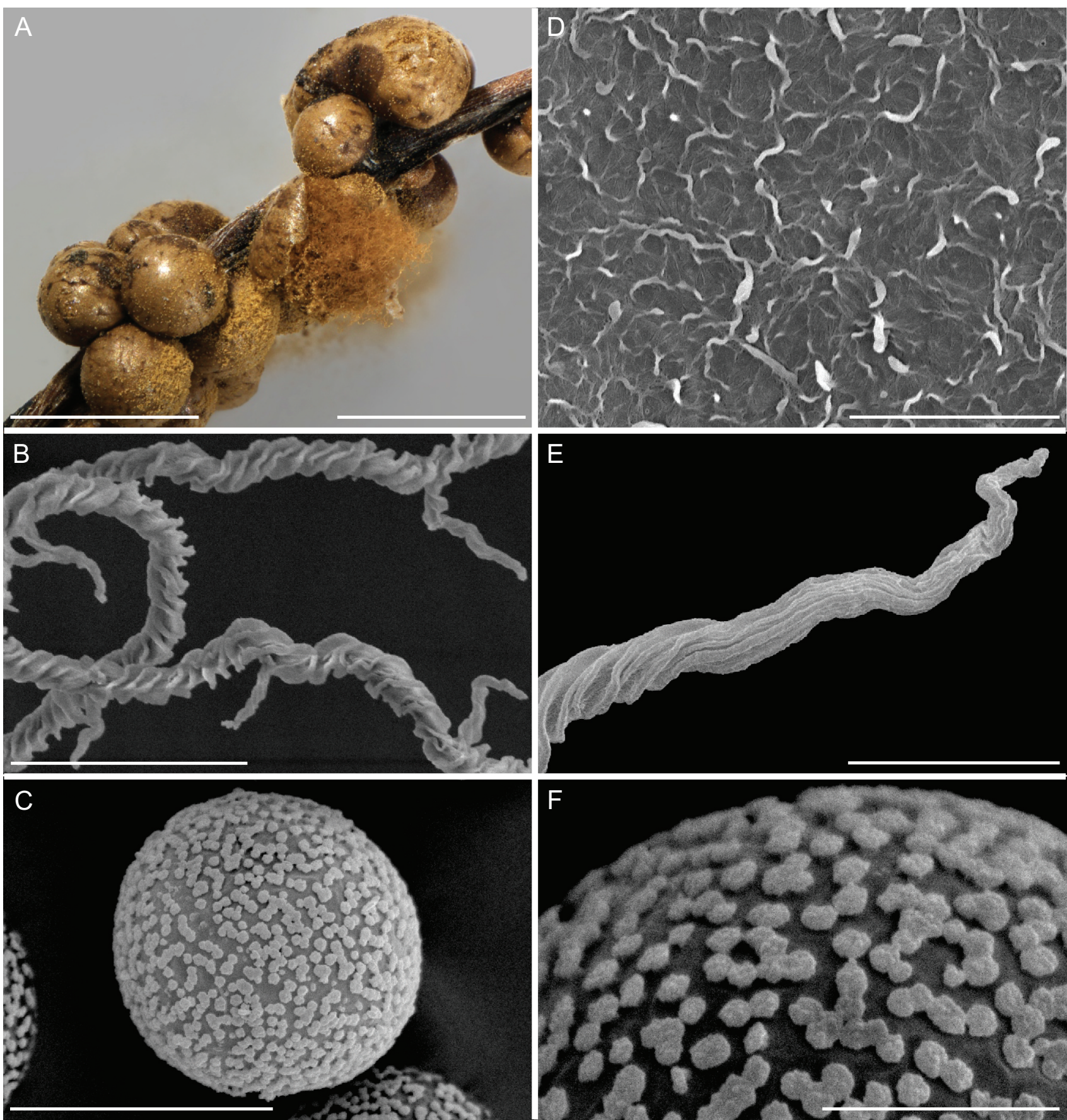

Figure 13. Trichia sordida. A. Group of sporocarps (Lado 20694). B. Capillitium (SEM) (Lado 20898). C. Spore (SEM) (Lado 20703). D. Peridium inner surface (SEM) (Lado 20898). E. Capillitial end (SEM) (Lado 20703). F. Details of spore ornamentation (SEM) (Lado 20703). Bars: $A=1 \mathrm{~mm} ; \mathrm{B}=30 \mu \mathrm{m} ; \mathrm{C}, \mathrm{E}=10 \mu \mathrm{m} ; \mathrm{D}=20 \mu \mathrm{m} ; \mathrm{F}=3 \mu \mathrm{m}$.

Comments: The spores of studied specimens are slightly smaller than those known from the literature for this species, e.g., (13.5-)14-15(-16.5) $\mu \mathrm{m}$ diam for the holotype (Johannesen 1984) or 12-15 $\mu \mathrm{m}$ diam for the holotype of the var. sordidoides (Illana et al. 1993). Due to the presence of many side branches and mostly semitrichioid type of the capillitium, they correspond with "form C" and "form D" (= T. sordida var. sordidoides) recognized by Kuhnt (2006).

\section{DISCUSSION}

Species diversity and composition.-The order Trichiales belongs to the bright-spored group, one of the main phylogenetic lineages of Myxomycetes (FioreDonno et al. 2005, 2019). In Europe, nivicolous representatives of this order are usually infrequent, in quantity of up to ca. 20 specimens per region, and taxonomically not diverse, exceptionally up to seven 
taxa recorded in some regions, but usually no more than two species (TABLE 2). Their role as the component of the nivicolous species group is thus marginal in the $\mathrm{NH}$, as best exemplified by the proportions of specimens found during a 4-year study in the German Alps, where out of 714 collections only three specimens (two species) represented Trichiales (Borg Dahl et al. 2018). Contribution of Trichiales to the snow bank communities of myxomycetes in Australia and New Zealand is even less significant according to available data (TABLE 2). Conversely, in the Andes, representatives of the order Trichiales constitute a group 10 times more numerous, in terms of specimen number (173 collections, ca. $22 \%$ ) than in other well-studied mountain massifs of the world (TABLE 2). It is also much more diverse there (15 taxa and two putative new species of Dianema are recognized), exceeding species diversity of the Stemonitidales (Ronikier and Lado 2015), which is the most representative and numerous taxonomic order in nivicolous assemblages of the NH. Thus, the diversity of Trichiales in nivicolous habitats in the Andes is unexpectedly high and shows a striking contrast between South America and remaining parts of the world.

It is noteworthy that specimens of the Trichiales were collected at 19 of 37 surveyed localities in the Andes (FIG. 1, TABLE 1, and Ronikier et al. 2013); thus, they seem to be more spatially widespread than specimens of the Stemonitidales (Ronikier and Lado 2015). Most of the recognized Trichiales taxa present in the Andes belong to the strictly nivicolous group of species, and three of them (plus two putative new Dianema species) seem to be exclusive to the Andes, since they have not been reported from other intensively studied mountains of the world. Some not strictly nivicolous species (common in the NH temperate regions where they occur later in the season), such as a cold-period species, Dianema depressum, and other typically autumnal species, Trichia contorta var. karstenii, T. affinis, and T. crateriformis, were present at nivicolous conditions at austral latitudes. All of them, however, occurred at single localities, and all but $T$. affinis were represented by one or two specimens. Remarkably, all non-nivicolous species were found at lower elevations, from forest to subalpine belt $(1364-1930 \mathrm{~m})$. Two putative Andean endemics, Hemitrichia crassifila and Perichaena megaspora, occurred at higher-elevation localities, above 2900 and $2200 \mathrm{~m}$, respectively, just as another strictly nivicolous species, Dianema subretisporum (2789 m). However, the third exclusive Andean taxon, Perichaena patagonica, together with two other nivicolous taxa, Trichia sordida and Trichia nivicola, was found at lower sites around $1400 \mathrm{~m}$. Only Trichia alpina was found both at forest and high mountain localities. The most frequently encountered species represent the putative endemic Perichaena megaspora (27 specimens, 17 localities, including a new Chilean record) and Hemitrichia crassifila (26 specimens, 9 localities).

The morphological variability observed in the Andean specimens of the order Trichiales remarkably confirms the pattern found in the same environments and geographic regions for the species of the order Stemonitidales (Ronikier and Lado 2015). Three different groups are recognizable: (i) species morphologically uniform across the entire distribution range and in all parts of the world (Dianema subretisporum, Trichia alpina, T. nivicola); (ii) species exclusive for the Andes and not found in other well-surveyed mountains of the world, i.e., putative endemic species (Hemitrichia crassifila, Perichaena patagonica, P. megaspora); and (iii) species morphologically diverse and divergent from populations in other regions of the world (Dianema sp.) that are confirmed by phylogenetic results that they represent distinct genetic lineages, but more collections are needed as well as a worldwide sampling of other known Dianema species to resolve a taxonomic position of the divergent group.

Table 2. Comparison of the share of Trichiales in mountain massifs of the Northern and Southern Hemispheres.

\begin{tabular}{|c|c|c|c|c|c|c|c|}
\hline Hemisphere & Mountain massif & All & $\operatorname{Tr}$ & $\%$ & Ts & $\mathrm{Tt}$ & $\%$ \\
\hline \multirow[t]{7}{*}{ Northern } & Sierra Nevada, Europe (Moreno et al. 2003) & 169 & 0 & 0 & 16 & 0 & 0 \\
\hline & Gredos Mts., Europe (Lado et al. 2005) & 100 & 8 & 8 & 21 & 2 & 9.5 \\
\hline & Gorce Mts., the Carpathians, Europe (Ronikier et al. 2008) & 148 & 5 & 3.4 & 18 & 1 & 5.6 \\
\hline & Pyrenees, Europe (Lado and Ronikier 2008, 2009) & 277 & 22 & 7.9 & 36 & 7 & 19.4 \\
\hline & Caucasus, Europe (Novozhilov et al. 2013) & 396 & 11 & 2.8 & 45 & 3 & 6.7 \\
\hline & Khibiny Mts., Europe (Erastova et al. 2017) & 666 & 19 & 2.8 & 32 & 1 & 3.1 \\
\hline & German Alps, Europe (Borg Dahl et al. 2018) & 714 & 3 & 0.4 & 33 & 2 & 6.1 \\
\hline \multirow[t]{3}{*}{ Southern } & Sounhern Alps, New Zealand (Stephenson and Johnston 2003) & 157 & 1 & 0.6 & 14 & 1 & 7.1 \\
\hline & $\begin{array}{l}\text { Snowy Mts. and Victorian Alps, Australia (Stephenson and } \\
\text { Shadwick 2009) }\end{array}$ & 295 & 1 & 0.3 & 13 & 1 & 7.7 \\
\hline & $\begin{array}{l}\text { Austral Andes, South America (this paper; Ronikier and Lado 2013, } \\
\text { 2015; Ronikier et al. 2013; Ronikier and Lado unpubl. data) }\end{array}$ & $790^{*}$ & $173^{*}$ & 21.9 & $48^{* *}$ & 15 & 31.2 \\
\hline
\end{tabular}

Note. All = total number of collections; $\mathrm{Tr}=$ number of collections of Trichiales; $\mathrm{Ts}=$ total number of species; $\mathrm{Tt}=$ total number of Trichiales species.

* Values based on all collections found, identified at least at the order level.

**Estimated value, material under taxonomic analysis. 
The presence of the species known from the NH together with several putative Andean endemics shows that the Andes are exceptionally rich in nivicolous Trichiales; thus, they may constitute an exceptionally important worldwide evolutionary hot spot and the center of the origin and diversification for the group. The Neotropics as an area of the origin of the myxomycetes was also suggested in the studies of two non-nivicolous species, Hemitrichia serpula (Scop.) Rostaf. ex Lister and Badhamia melanospora Speg. (Aguilar et al. 2014; Dagamac et al. 2017).

\section{Phylogenetic affinity of the Andean endemics in the context of the phylogeny of Trichiales. -} Although there is a long tradition of myxomycete studies, especially intense since the last decade of the19th century when the first monograph of the group appeared (Rostafiński 1874, 1875), molecular methods were introduced in studies of this group relatively late in comparison with other eukaryotes (Walker et al. 2017). Consequently, the bright-spored group of Myxomycetes still suffers from scarcity of reference DNA sequences (Fiore-Donno et al. 2013; Schnittler et al. 2017) necessary to elucidate the phylogenetic position of species and find a proper delimitation of genera. Only two non-nivicolous species of Trichiales, Trichia varia (Feng and Schnittler 2015) and Hemitrichia serpula (Dagamac et al. 2017), have been analyzed in detail using molecular techniques, and their DNA sequences are well represented in the GenBank repository. Other species of Trichiales remain not or poorly characterized genetically. Low representation of available sequences of bright-spored myxomycetes is the main limitation in the phylogenetic analyses of the group. The group as a whole is monophyletic (Fiore-Donno et al. 2005, 2019), whereas the segregation into genera traditionally recognized based on morphological traits is not confirmed by molecular data. Traditionally, Trichiales contains 14 morphologically distinguishable genera (Lado and Eliasson 2017), none of which appears to be monophyletic (e.g., Fiore-Donno et al. 2013, 2019; Walker et al. 2015; Feng and Schnittler 2017). Our phylogenetic analyses confirm polyphyletic character of genera in Trichiales and demonstrate that each newly morphologically recognized taxon appears to be phylogenetically distinct (FIG. 2).

The most difficult to interpret group based on morphology were the specimens of Dianema. Dianema sp. 1 associates specimens with clustered and free spores. Aggregation of spores in the form of more or less firmly attached clusters is a character considered important in myxomycete taxonomy at a species level (Keller et al. 2017). About 30 species from various myxomycete genera have clustered spores, but the taxonomic importance of this character was already questioned (Schnittler and Mitchell 2000). These authors hypothesize that most of the cluster-spored species have a possible free-spored counterpart. Our phylogenetic results also indicate that this spore characteristic (clustered vs. free) may be of lesser importance, at least in some representatives of Dianema.

In previous studies, two species of Dianema, D. nivale and $D$. inconspicuum, clustered together, forming a monophyletic clade close to Prototrichia metallica and Calomyxa metallica (Berk.) Nieuwl. (Fiore-Donno et al. 2013). With the enlarged species sampling, our phylogenetic results show two sister clades incorporating Dianema species. One clade contains D. nivale and D. inconspicuum, whereas the sister clade contains D. harveyi, Prototrichia metallica (type species of Prototrichia), and Dianema sp. 1. The close position of the two type species of the genera Prototrichia and Dianema may suggest that they are congeneric, with the generic name Prototrichia available for the representatives of the clade due to priority.

Traditionally defined Hemitrichia is characterized by branched capillitium ornamented with spiral bands, in contrast to Trichia defined by unbranched capillitium (e.g., Poulian et al. 2011). In the previous two-gene phyogeny (Fiore-Donno et al. 2013), the genus Hemitrichia was recognized as a group characterized additionally by the presence of spore-like bodies filling the stalk, but the type species of Hemitrichia was not included there. We failed to obtain molecular data for $H$. clavata (Pers.) Rostaf., type species of the genus Hemitrichia, but Feng and Schnittler (2017) showed that the species nests well within this clade, forming a group of Hemitrichia s. str. They also demonstrated Hemitrichia to be polyphyletic. Our results confirm the polyphyletic character of the genus Hemitrichia and show that the newly proposed species, $H$. crassifila, occupies a separate position sister to Perichaena corticalis (type species of Perichaena) and Trichia varia (type species of Trichia) and distant from the most similar morphologically H. intorta (FIG. 2). Our phylogenetic results contradict proposition of the new species in the genus Hemitrichia s. str., but because of largely unresolved phylogeny of Trichiales, we are not able to propose a new genus that would be morphologically and phylogenetically confirmed. Thus, being aware that the new species is not closely related to the type species of the genus Hemitrichia, we have no other option but propose the new species in a traditionally, morphologically defined genus Hemitrichia.

Polyphyletic character of the genus Perichaena shown by Walker at al. (2015) and Feng and Schnittler (2017) is 
supported by our two-gene phylogeny as well. The new clade recognized in our phylogeny (FIG. 2) composed of three species, Perichaena vermicularis, the recently described P. megaspora (Ronikier et al. 2013), and the newly described here $P$. patagonica, shows closer affinity to Cornuvia serpula (Wigand) Rostaf. (type species of Cornuvia, a monospecific genus) than to P. corticalis (type species of Perichaena). Cornuvia serpula has a very characteristic type of capillitium ornamented with rings, whereas the capillitium of all three Perichaena species are typical Perichaena-like, branched, hollow threads, smooth, warted, or spiny. Therefore, based on the morphological species concept and traditional separation of genera based mostly on capillitium characters (Clark and Haskins 2014), it is clear that the three Perichaena species cannot be classified within Cornuvia. Like in the case of Hemitrichia crassifila, we have no other option but propose the new species, Perichaena patagonica, in the genus Perichaena, based on traditional, morphological species concept.

Polyphyletic character of most genera in the order Trichiales and contradiction between the phylogeny and traditional segregation of genera based on capillitium type and ornamentation clearly indicate that no final taxonomic conclusions can be made in the group. Therefore, there is an urgent need to build a multigene phylogeny of Trichiales based on a wide species sampling including type species of genera.

\section{ACKNOWLEDGMENTS}

We thank Marianne Meyer and the curators of the following herbaria: $\mathrm{AH}, \mathrm{BM}, \mathrm{BPI}, \mathrm{BR}, \mathrm{KR}, \mathrm{KRAM}, \mathrm{M}, \mathrm{MA}$, and $\mathrm{O}$, for loan of the comparative material, Yolanda Ruiz and Anna Łatkiewicz for their technical assistance with SEM, Carlos de Mier for his help with the photographs, Anna-Maria FioreDonno for making available an alignment of the bright-spored phylogeny published by Fiore-Donno et al. (2013), Michał Ronikier for a critical reading of the manuscript, and two anonymous reviewers and especially the editor, P. Brandon Matheny, for valuable comments improving this study.

\section{Funding}

This research was supported by the Spanish government (grants CGL2014-52584P and PGC2018-094660-B-I00), the Polish National Science Centre (grant N N303 799440), the statutory fund of the W. Szafer Institute of Botany of the Polish Academy of Sciences, and the SYNTHESYS Project financed by European Community Research Infrastructure Action under the FP7 "Capacities" Program at Real Jardín Botánico (CSIC), granted to Anna Ronikier (ES-TAF 160).

\section{ORCID}

Anna Ronikier (D) http://orcid.org/0000-0003-0193-8685
Iván García-Cunchillos (D) http://orcid.org/0000-0002-58307529

Paulina Janik (D) http://orcid.org/0000-0002-4106-636X

Carlos Lado (D) http://orcid.org/0000-0002-6135-2873

\section{LITERATURE CITED}

Aguilar M, Fiore-Donno AM, Lado C, Cavalier-Smith T. 2013. Using environmental niche models to test the 'everything is everywhere' hypothesis for Badhamia. ISME Journal 8:737-745.

Borg Dahl M, Shchepin O, Schunk Ch, Menzel A, Novozhilov YK, Schnittler M. 2018. A four year survey reveals a coherent pattern between occurrence of fruit bodies and soil amoebae populations for nivicolous myxomycetes. Scientific Reports 8:11662.

Bozonnet J, Meyer M, Poulain M. 1991. Espèces nivales de myxomycètes. Bulletin, Société d'Histoire Naturelle du Pays de Montbéliard: 51-72.

Chachuła P, Fiedor M, Ronikier A. 2017. First record of a cold-period myxomycete species Dianema depressum (Lister) Lister in Poland. Acta Mycologica 52:1095.

Cheesman WN, Lister G. 1915. Mycetozoa of Australia and New Zealand. Journal of Botany 53:203-212.

Chernomor O, von Haeseler A, Minh BQ. 2016. Terrace aware data structure for phylogenomic inference from supermatrices. Systematic Biology 65:997-1008.

Clark J, Haskins EF. 2014. Sporophore morphology and development in the myxomycetes: a review. Mycosphere 5:153-170.

Dagamac NHA, Rojas C, Novozhilov YK, Moreno GH, Schlueter R, Schnittler M. 2017. Speciation in progress? A phylogeographic study among populations of Hemitrichia serpula (Myxomycetes). PLoS ONE 12: e0174825.

Demaree RS, Kowalski DT. 1975. Fine structure of myxomycetes with clustered spores. Journal of Protozoology 22:85-88

Erastova DA, Novozhilov YK, Schnittler M. 2017. Nivicolous myxomycetes of the Khibiny Mountains, Kola peninsula, Russia. Nova Hedwigia 104:85-110.

Feng Y, Schnittler M. 2015. Sex or no sex? Group I introns and independent marker genes reveal the existence of three sexual but reproductively isolated biospecies in Trichia varia (Myxomycetes). Organisms Diversity and Evolution 15:631-650.

Feng Y, Schnittler M. 2017. Molecular or morphological species? Myxomycete diversity in a deciduous forest in northeastern Germany. Nova Hedwigia 104:359-380. doi:10.1127/nova_hedwigia/2016/0326

Fiore-Donno AM, Berney C, Pawlowski J, Baldauf SL. 2005. Higher-order phylogeny of plasmodial slime molds (Myxogastria) based on elongation factor 1-A and small subunit rRNA gene sequences. Journal of Eukaryotic Microbiology 52:201-210.

Fiore-Donno AM, Clissmann F, Meyer M, Schnittler M, Cavalier-Smith T. 2013. Two-gene phylogeny of bright-spored myxomycetes (slime moulds, superorder Lucisporidia). PLoS ONE 8:e62586.

Fiore-Donno AM, Kamono A, Meyer M, Schnittler M, Fukui M, Cavalier-Smith T. 2012. 18S rDNA phylogeny of 
Lamproderma and allied genera (Stemonitales, Myxomycetes, Amoebozoa). PLoS ONE 7:e35359.

Fiore-Donno AM, Tice AK, Brown MW. 2019. A non-flagellated member of the Myxogastria and expansion of the Echinosteliida. Journal of Eukaryotic Microbiology 66:538-544

Huelsenbeck JP. 2004. Bayesian phylogenetic model selection using reversible jump Markov chain Monte Carlo. Molecular Biology and Evolution 21:1123-1133.

Huelsenbeck JP, Ronquist F. 2001. MRBAYES: Bayesian inference of phylogenetic trees. Bioinformatics 17:754-755.

Illana C, Moreno G, Castillo A. 1993. Spanish myxomycetes. VIII. Some nivicolous myxomycetes from Central Spain. Cryptogamie Mycologie 14:241-253.

Janik P, Ronikier M, Ronikier A. 2020. New protocol for successful isolation and amplification of DNA from exiguous fractions of specimens: a tool to overcome the basic obstacle in molecular analyses of myxomycetes. PeerJ 8:e8406.

Kalyaanamoorthy S, Minh BQ, Wong TKF, von Haeseler A, Jermiin LS. 2017. ModelFinder: fast model selection for accurate phylogenetic estimates. Nature Methods 14:587-589.

Kang S, Tice AK, Spiegel FW, Silberman JD, Pánek T, Čepička I, Kostka M, Kosakyan A, Alcântara DMC, Roger AJ, Shadwick LL, Smirnov A, Kudryavstev A, Lahr DJG, Brown MW. 2017. Between a pod and a hard test: the deep evolution of Amoebae. Molecular Biology and Evolution 34:2258-2270.

Katoh K, Standley DM. 2013. MAFFT multiple sequence alignment software version 7: improvements in performance and usability. Molecular Biology and Evolution 30:772-780.

Keller HW, Everhart SE, Kilgore CM. 2017. The Myxomycetes: introduction, basic biology, life cycles, genetics, and reproduction. In: Stephenson S, Rojas C, eds. Myxomycetes. Biology, systematics, biogeography and ecology. Cambridge, MA: Academic Press. p. 1-40.

Kowalski DT. 1968. Observations on the Dianemaceae. Mycologia 59:1075-1084.

Kuhnt A. 2006. Nivicole Myxomyceten aus Deutschland (unter besonderer Berücksichtigung der bayerischen Alpen). Teil II. Zeitschrift für Mykologie 72:101-113.

Kuhnt A. 2019. Bemerkenswerte Myxomycetenfunde: neue Arten, Neukombinationen und Nachweise seltener Arten, Teil 2. Brichte der Bayerischer Botanischen Gesellschaft 89:139-222.

Lado C. 2004. Nivicolous myxomycetes of the Iberian Peninsula: considerations on species richness and ecological requirements. Systematics and Geography of Plants 74:143-157.

Lado C, Eliasson U. 2017. Taxonomy and systematics: current knowledge and approaches on the taxonomic treatment of myxomycetes. In: Stephenson S, Rojas C, eds. Myxomycetes. Biology, systematics, biogeography and ecology. Cambridge, MA: Academic Press. p. 205-251.

Lado C, Estrada-Torres A, Stephenson SL. 2007. Myxomycetes collected in the first phase of a north-south transect in Chile. Fungal Diversity 25:81-101.

Lado C, Pando F. 1997. Myxomycetes, I. Ceratiomyxales, Echinosteliales, Liceales, Trichiales. Flora Mycologica Iberica. Vol. 2. Stuttgart, Germany: J. Cramer. 323 p.

Lado C, Ronikier A. 2008. Nivicolous myxomycetes from the Pyrenees-notes on taxonomy and species diversity 1 . Physarales and Trichiales. Nova Hedwigia 87:337-360.
Lado C, Ronikier A. 2009. Nivicolous myxomycetes from the Pyrenees-notes on taxonomy and species diversity 2 . Stemonitales. Nova Hedwigia 89:131-145. doi:10.1127/ 0029-5035/2009/0089-0131

Lado C, Ronikier A, Ronikier M, Drozdowicz A. 2005. Nivicolous myxomycetes from Sierra de Gredos (central Spain). Nova Hedwigia 81:371-394.

Lado C, Wrigley de Basanta D. 2008. A review of neotropical Myxomycetes (1828-2008). Anales del Jardín Botánico de Madrid 65:211-254.

Lado C, Wrigley de Basanta D. 2018. Typification of the myxomycete taxa described by Listers and preserved at the Natural History Museum, London (BM). Phytotaxa Monograph 341:1-83.

Lado C, Wrigley de Basanta D, Estrada-Torres A. 2011. Biodiversity of Myxomycetes from the Monte Desert of Argentina. Anales del Jardín Botánico de Madrid 68:61-95.

Lado C, Wrigley de Basanta D, Estrada-Torres A, García Carvajal E, Aguilar M, Hernández-Crespo JC. 2009. Description of a new species of Perichaena (Myxomycetes) from arid areas of Argentina. Anales del Jardín Botánico de Madrid 66 (S1):63-70.

Lado C, Wrigley de Basanta D, Estrada-Torres A., García-Carvajal E. 2014. Myxomycete diversity of the Patagonian Steppe and bordering areas of Argentina. Anales del Jardín Botánico de Madrid 71: e006.

Lado C, Wrigley de Basanta D, Estrada-Torres A, Stephenson SL. 2016. Myxomycete diversity in the coastal desert of Peru with emphasis on the lomas formations. Anales del Jardín Botánico de Madrid 73:e032.

Lado C, Wrigley de Basanta D, Estrada-Torres A, Stephenson SL. 2013. The biodiversity of myxomycetes in central Chile. Fungal Diversity 59:3-32.

Larget B, Simon DL. 1999. Markov Chasin Monte Carlo algorithms for the Bayesian analysis of phylogenetic trees. Molecular Biology and Evolution 16:750-759.

Lister A. 1891. Notes on Mycetozoa. Journal of Botany 29:257-268.

Lister A, Lister G. 1905. Mycetozoa from New Zealand. Journal of Botany 43:111-114.

Liu Q-S, Yan S-Z, Chen S-L. 2015. Species diversity of myxomycetes associated with different terrestrial ecosystems, substrata (microhabitats) and environmental factors. Mycological Progress 14:27.

Martin GW. 1962. Taxonomic notes on Myxomycetes, IV. Brittonia 14:180-185.

Martin GW. 1963. A new name in Trichia. Mycologia 55:131.

Martin GW, Alexopoulos CJ. 1969. The Myxomycetes. Iowa City, Iowa: University of Iowa Press. 560 p.

McHugh R. 2009. Field and moist chamber collections of Paraguay myxomycetes. Karstenia 48:49-56.

Meylan Ch. 1910. Myxomycètes du Jura (suite). Bulletin de la Société Vaudoise des Sciences Naturelles 46:49-57.

Meylan Ch. 1932. Les espèces nivales du genre Lamproderma. Bulletin de la Société Vaudoise des Sciences Naturelles 57:359-373.

Mitchell DW. 1992. The Myxomycota of New Zealand and its island territories. Nova Hedwigia 55:231-256.

Moreno G, Castillo A. 2013. A comparative study of the types of three species of Myxomycetes: Trichia crateriformis, T. fallax var. olivacea and T. ferbankensis. Boletin de la Sociedad Micológica de Madrid 37:85-98. 
Moreno G, Sánchez A., Castillo A., Singer H., Illana C. 2003. Nivicolous myxomycetes from the Sierra Nevada National Park (Spain)Mycotaxon 87:223-242.

Neubert H, Nowotny W, Baumann K. 1993. Die Myxomyceten Deutschlands und des angrenzenden Alpenraumes unter besonderer Berücksichtigung Österreichs. Band 1. Ceratiomyxales, Echinosteliales, Liceales, Trichiales. Gomaringen, Germany: Karlheinz Baumann. 343 p.

Nguyen LT, Schmidt HA, von Haeseler A, Minh BQ. 2015. IQTREE: a fast and effective stochastic algorithm for estimating maximum-likelihood phylogenies. Molecular Biology and Evolution 32:268-274.

Novozhilov YK, Schnittler M, Erastova DA, Okun MV, Schepin ON, Heinrich E. 2013. Diversity of nivicolous myxomycetes of the Teberda State Biosphere Reserve (Northwestern Caucasus, Russia). Fungal Diversity 59:109-130.

Poulain M, Meyer M, Bozonnet J. 2011. Les Myxomycètes. Tome $1 \& 2$. Sevrier, France: Fédération mycologique et botanique Dauphiné-Savoie. 568 p. + 544 pl.

Rambaut A, Drummond AJ, Xie D, Baele G, Suchard MA. 2018. Posterior summarization in Bayesian phylogenetics using Tracer 1.7. Systematic Biology 67:901-904.

Rammeloo J. 1974. Structure of the epispore in the Trichiaceae (Trichiales, Myxomycetes), as seen with the scanning electron microscope. Bulletin de la Société Royale de Botanique de Belgique 107:353-359.

Rawson SH. 1937. A List of the Mycetozoa Collected Chiefly in the Vicinity of Dunedin, New Zealand. Transactions and Proceedings of the Royal Society of New Zealand 66:351-353.

Ronikier A, Lado C. 2013. Physarum andinum, a new nivicolous species of myxomycete from the Patagonian Andes. Mycologia 105:162-171.

Ronikier A, Lado C. 2015. Nivicolous Stemonitales from the Austral Andes: analysis of morphological variability, distribution and phenology as a first step toward testing the large-scale coherence of species and biogeographical properties. Mycologia 107:258-283.

Ronikier A, Lado C, Wrigley de Basanta D. 2013. Perichaena megaspora, a new nivicolous species of myxomycete from the Andes. Mycologia 105:938-944.

Ronikier A, Ronikier M., Drozdowicz A. 2008. Diversity of nivicolous myxomycetes in the Gorce mountains - a low-elevation massif of the western Carpathians. Mycologia 10:337-352.

Ronikier A, Ronikier M. 2009. How 'alpine' are nivicolous myxomycetes? A worldwide assessment of altitudinal distribution. Mycologia 101:1-16.

Ronquist F, Teslenko M, van der Mark P, Ayres DL, Darling A, Höhna S, Larget B, Liu L, Suchard MA, Huelsenbeck JP. 2012. MrBayes 3.2: efficient Bayesian phylogenetic inference and model choice across a large model space. Systematic Biology 61:539-542.

Rostafiński J. 1874. Śluzowce (Mycetozoa). Pamiętnik Towarzystwa Nauk Ścisłych w Paryżu 5:1-215.

Rostafiński J. 1875. Śluzowce (Mycetozoa). Ciąg dalszy. Pamiętnik Towarzystwa Nauk Ścisłych w Paryżu 6:216-432.
Schnittler M, Dagamac NHA, Novozhilov YK. 2017. Biogeographical patters in Myxomycetes. In: Stephenson S, Rojas C, eds. Myxomycetes. Biology, systematics, biogeography and ecology. Cambridge, MA: Academic Press. p. 299-331.

Schnittler M, Mitchell DW. 2000. Species diversity in myxomycetes based on the morphological species concept-a critical examination. Stapfia 73:55-62.

Stephenson SL. 2003. Myxomycetes of New Zealand. Fungi of New Zealand. Volume 3. Fungal Diversity Research Series $11: 1-238$.

Stephenson SL, Johnston PR. 2003. Myxomycetes and fungi associated with alpine snowbank habitats in New Zealand. Australasian Mycologist 22:20-26.

Stephenson SL, Laursen GA, Seppelt RD. 2007. Myxomycetes of subantarctic Macquarie Island. Australian Journal of Botany 55:439-449.

Stephenson SL., Shadwick DL. 2009. Nivicolous myxomycetes from alpine areas of south-eastern Australia. Austral J Bot 57:116-122.

Stephenson SL, Schnittler M, Novozhilov YK. 2008. Myxomycete diversity and distribution from the fossil record to the present. Biodiversity and Conservation 17:285-301.

Thiers B. [continuously updated]. Index Herbariorum: a global directory of public herbaria and associated staff. New York Botanical Garden's Virtual Herbarium. [cited 2019 May]. Available from: http://sweetgum.nybg.org/ science/ih/.

Turland NJ, Wiersema JH, Barrie FR, Greuter W, Hawksworth DL, Herendeen PS, Knapp S, Kusber W-H, Li D-Z, Marhold K, Herendeen PS, Knapp S, Kusber W-H, Li D-Z, Marhold K, May TW, McNeill J, Monro AM, Prado J, Price MJ, Smith GF 2018. International Code of Nomenclature for algae, fungi, and plants (Shenzhen Code) adopted by the Nineteenth International Botanical Congress Shenzhen, China, July 2017. Regnum Vegetabile no. 159. Glashütten, Germany: Koeltz Botanical Books. 254 p.

Walker LM, Hoppe Th, Silliker ME. 2017. Molecular techniques and current research approaches. In: Stephenson S, Rojas C, eds. Myxomycetes. Biology, systematics, biogeography and ecology. Cambridge, MA: Academic Press. p. 145-173.

Walker LM, Leontyev DV, Stephenson SL. 2015. Perichaena longipes, a new myxomycete from the Neotropics. Mycologia 107:1012-1022.

Wrigley de Basanta D, Estrada-Torres A, García-Cunchillos I, Cano Echevarría A, Lado C. 2017. Didymium azorellae, a new myxomycete from cushion plants of cold arid areas of South America. Mycologia 109:993-1002.

Wrigley de Basanta D, Lado C, Estrada-Torres A, Stephenson SL. 2010. Biodiversity of myxomycetes in subantarctic forests of Patagonia and Tierra del Fuego, Argentina. Nova Hedwigia 90:45-79.

Wrigley de Basanta D, Lado C, Estrada-Torres A, Stephenson SL. 2013. Biodiversity studies of myxomycetes in Madagascar. Fungal Diversity 59:55-83.

Wrigley de Basanta D, Lado C, García-Martín JM, EstradaTorres A. 2015. Didymium xerophilum, a new myxomycete from the tropical Andes. Mycologia 107:157-168. 